\title{
The House of Experiment in Seventeenth-Century England
}

\section{Citation}

Shapin, Steven. 1988. The house of experiment in seventeenth-century England. Isis 79(3): 373-404.

\section{Published Version}

http://dx.doi.org/10.1086/354773

\section{Permanent link}

http://nrs.harvard.edu/urn-3:HUL.InstRepos:3403053

\section{Terms of Use}

This article was downloaded from Harvard University's DASH repository, and is made available under the terms and conditions applicable to Other Posted Material, as set forth at http:// nrs.harvard.edu/urn-3:HUL.InstRepos:dash.current.terms-of-use\#LAA

\section{Share Your Story}

The Harvard community has made this article openly available.

Please share how this access benefits you. Submit a story.

Accessibility 


\title{
The House of Experiment in Seventeenth-Century England
}

\author{
By Steven Shapin*
}

That which is not able to be performed in a private house will much less be brought to pass in a commonwealth and kingdom.

-William Harrison, The Description

of England (1587)

$\mathrm{M}$

Y SUBJECT is the place of experiment. I want to know where experimental science was done. In what physical and social settings? Who was in attendance at the scenes in which experimental knowledge was produced and evaluated? How were they arrayed in physical and social space? What were the conditions of access to these places, and how were transactions across their thresholds managed?

The historical materials with which I am going to deal are of special interest. Seventeenth-century England witnessed the rise and institutionalization of a program devoted to systematic experimentation, accompanied by a literature explicitly describing and defending practical aspects of that program. Nevertheless, aspects of the historiography manifest in this paper may prove of more general interest. Historians of science and ideas have not, in the main, been much concerned with the siting of knowledge production. ${ }^{1}$ This essay offers reasons for systematically studying the venues of knowledge. I want to display the network of connections between the physical and social setting of inquiry and the position of its products on the map of knowledge. I shall try to demonstrate how the siting of knowledge-making practices contributed toward a practical solution of epistemological problems. The physical and the symbolic siting of experimental work was a way of bounding and disciplining the community of practitioners, it was a

* Science Studies Unit, Edinburgh University, 34 Buccleuch Place, Edinburgh EH8 9JT Scotland. For criticisms of earlier versions of this paper, I thank Peter Galison, J. V. Golinski, Owen Hannaway, Adi Ophir, Trevor Pinch, Simon Schaffer, and members of seminars at the universities of Bath, Harvard, Illinois, London (University College), Melbourne, Oxford, Pennsylvania, and the Hebrew University of Jerusalem. For permission to quote from the Boyle Papers, I thank the Council of the Royal Society of London.

1 An outstanding exception is Owen Hannaway, "Laboratory Design and the Aim of Science: Andreas Libavius versus Tycho Brahe," Isis, 1986, 77:585-610. See also Peter Galison, "Bubble Chambers and the Experimental Workplace," in Observation, Experiment, and Hypothesis in Modern Physical Science, ed. Peter Achinstein and Owen Hannaway (Cambridge, Mass.: MIT Press, 1985), pp. 309-373; Larry Owens, "Pure and Sound Government: Laboratories, Playing Fields, and Gymnasia in the Nineteenth-Century Search for Order," Isis, 1985, 76:182-194; and, although not concerned with knowledge-making processes, Sophie Forgan, "Context, Image and Function: A Preliminary Enquiry into the Architecture of Scientific Societies," The British Journal for the History of Science, 1986, 19:89-113. 
way of policing experimental discourse, and it was a way of publicly warranting that the knowledge produced in such places was reliable and authentic. That is to say, the place of experiment counted as a partial answer to the fundamental question, Why ought one to give one's assent to experimental knowledge claims?

I start by introducing some connections between empiricist processes of knowledge making and the spatial distribution of participants, pointing to the ineradicable problem of trust that is generated when some people have direct sensory access to a phenomenon and others do not. I then mobilize some information about where experimental work was in fact performed in mid to late seventeenth-century England, focusing upon sites associated with the work of the early Royal Society and two of its leading fellows, Robert Boyle and Robert Hooke. The question of access to these sites is then considered: who could go in and how was the regulation of entry implicated in the evaluation of experimental knowledge? The public display of the moral basis of experimental practices depended upon the form of social relations obtaining within these sites as much as it did upon who was allowed within. Indeed, these considerations were closely related, and I discuss how the condition of gentlemen and the deportment expected of them in certain places bore upon experimental social relations and, in particular, upon the problems attending the assessment of experimental testimony. The paper concludes by analyzing how the stages of experimental knowledge making mapped onto physical and symbolic patterns of movements within the rooms of a house, particularly the circulation between private and public places.

\section{ON THE THRESHOLD OF EXPERIMENT}

The domestic threshold marks the boundary between private and public space. Few distinctions in social life are more fundamental than that between private and public. ${ }^{2}$ The same applies to the social activities we use to make and evaluate knowledge. On either side of the threshold the conditions of our knowledge are different. While we stand outside, we cannot see what goes on within, nor can we have any knowledge of internal affairs but what is related to us by those with rights of access or by testimony still more indirect. What we cannot see, we must take on trust or, trust being withheld, continue to suspect. Social life as a whole and the social procedures used to make knowledge are spatially organized. ${ }^{3}$ The threshold is a social marker: it is put in place and maintained by social decision

\footnotetext{
2 See, e.g., Erving Goffman, The Presentation of Self in Everyday Life (London: Allen Lane, Penguin Press, 1969), Ch. 3; Richard Sennett, The Fall of Public Man (Cambridge: Cambridge Univ. Press, 1974), esp. Ch. 5; Shirley Ardener, "Ground Rules and Social Maps for Women: An Introduction," in Women and Space: Ground Rules and Social Maps, ed. Ardener (London: Croom Helm, 1981), Ch. 1; Clark E. Cunningham, "Order in the Atoni House," in Right \& Left: Essays on Dual Symbolic Classification, ed. Rodney Needham (Chicago: Univ. Chicago Press, 1973), pp. 204-238.

${ }^{3}$ Anthony Giddens, The Constitution of Society: Outline of the Theory of Structuration (Cambridge: Polity Press, 1984), Ch. 3 (esp. his discussion of the work of the Swedish geographer Torsten Hägerstrand); Bill Hillier and Julienne Hanson, The Social Logic of Space (Cambridge: Cambridge Univ. Press, 1984), esp. pp. ix-xi, 4-5, 8-9, 19. For Foucauldian perspectives see Michel Foucault, "Questions on Geography," in Foucault, Power/Knowledge: Selected Interviews and Other Writings, 1972-1977, ed. Colin Gordon (Brighton: Harvester Press, 1980), pp. 63-77; Foucault, Discipline and Punish: The Birth of the Prison, trans. Alan Sheridan (New York: Vintage, 1979); and Adi Ophir, "The City and the Space of Discourse: Plato's Republic-Textual Acts and Their Political Significance" (Ph.D. diss., Boston Univ., 1984).
} 
and convention. Yet once in place it acts as a constraint upon social relations. The threshold acts as a constraint upon the distribution of knowledge, its content, quality, conditions of possession, and justification, even as it forms a resource for stipulating that the knowledge in question really is the thing it is said to be.

Within empiricist schemes of knowledge the ultimate warrant for a claim to knowledge is an act of witnessing. The simplest knowledge-producing scene one can imagine in an empiricist scheme would not, strictly speaking, be a social scene at all. It would consist of an individual, perceived as free and competent, confronting natural reality outside the social system. Although such a scene might plausibly be said to be the paradigm case of knowledge production in seventeenth-century empiricist writings, it was not, in fact, recommended by the writers. Three sorts of problems were recognized to attend the privacy of solitary individual observation. ${ }^{4}$ First, the transformation of mere belief into proper knowledge was considered to consist of the transit from the perceptions and cognitions of the individual to the culture of the collective. Empiricist writers therefore looked for the means by which such a successful transit might be managed. The second problem was connected with the view that the perceptions of postlapsarian man were corrupt and were subject to biases deriving from interest. Although these factors could not be eliminated, their consequences might be mitigated by ensuring that both witnessing and the consideration of knowledge claims took place in a social setting. Third, there were often contingent practical problems attending the circumstances of observation, which meant that social relations of some kind had to be established for the phenomena in question to be dealt with. Certain observations, particularly in the natural history sciences but also in experimental science, could, for instance, be made only by geographically privileged persons. In such cases there was no practical way by which a witnessing public could be brought to the phenomena or the phenomena brought to the public. Testimony was therefore crucial: the act of receiving testimony constituted a rudimentary social scene, and the evaluation of testimony might occur in an elaborately constructed social scene.

English empiricists did not think that testimony could be dispensed with, but they worked strenuously to manage and discipline it. Most empiricist writers recognized that the bulk of knowledge would have to be derived from what one was told by those who had witnessed the thing in question, or by those who had been told by those who had been told, and so on. If, however, trust was to be a basis for reliable knowledge, the practical question emerged: Whom was one to trust? John Locke, among others, advised practitioners to factor the creditworthiness of the source by the credibility of the matter claimed by that source. ${ }^{5}$ One might accept the report of an implausible phenomenon from a creditworthy

\footnotetext{
${ }^{4}$ For a survey of the evaluation of evidence in this setting, see Barbara J. Shapiro, Probability and Certainty in Seventeenth-Century England: A Study of the Relationships between Natural Science, Religion, History, Law, and Literature (Princeton, N.J.: Princeton Univ. Press, 1983), esp. Ch. 2; for treatment of experimental practice in these connections, see Steven Shapin and Simon Schaffer, Leviathan and the Air-Pump: Hobbes, Boyle, and the Experimental Life (Princeton, N.J.: Princeton Univ. Press, 1985), esp. Ch. 2.

5 John Locke, Essay Concerning Human Understanding, in Locke, Works, 10 vols. (London, 1823), Vol. III, on pp. 97-100; and John Dunn, "The Concept of 'Trust' in the Politics of John Locke," in Philosophy in History: Essays on the Historiography of Philosophy, ed. Richard Rorty, J. B. Schneewind, and Quentin Skinner (Cambridge: Cambridge Univ. Press, 1984), pp. 279-301.
} 
source and reject plausible claims from sources lacking that creditworthiness. Credibility as an attribute ascribed to people was not, therefore, independent of theories of what the world was like. One might calibrate persons' credibility by what it was they claimed to have witnessed, just as one might use their accepted credibility to gauge what existed in the world. ${ }^{6}$ Nevertheless, credibility had other sources: certain kinds of people were independently known to be more trustworthy sources than others. Roughly speaking, the distribution of credibility followed the contours of English society, and that it did was so evident that scarcely any commentator felt obliged to specify the grounds of this creditworthiness. In such a setting one simply knew what sorts of people were credible, just as one simply knew whose reports were suspect. ${ }^{7}$ Indeed, in certain instances Robert Boyle recommended that one ought to credit the testimony of things rather than the testimony of certain types of persons. Discussing one of his hydrostatical experiments of the $1660 \mathrm{~s}$, Boyle argued that "the pressure of the water in our . . . experiment having manifest effects upon inanimate bodies, which are not capable of giving us partial informations, will have much more weight with unprejudiced persons, than the suspicious, and sometimes disagreeing accounts of ignorant divers, whom prejudicate opinions may much sway, and whose very sensations, as those of other vulgar men, may be influenced by predispositions, and so many other circumstances, that they may easily give occasion to mistakes."8 When in 1667 the Royal Society wished to experiment on the transfusion of animal blood into a human being, they hit upon an ingenious solution to the problem of testimony posed by such an experiment. The subject, Arthur Coga, was indigent and possibly mad (so it was expedient to use him), but he was also a Cambridge graduate (so his testimony of how he felt on receipt of sheep's blood might be credited). ${ }^{9}$

\section{EXPERIMENTAL SITES}

One of the considerations that recommended the program of systematic artificial experimentation launched in the middle of the seventeenth century by Boyle and his associates was that experimental phenomena could be arranged and produced at specified times and places. Such phenomena were disciplined, and disciplined

\footnotetext{
6 This is an observational version of what Harry Collins has called "the experimenter's regress": H. M. Collins, Changing Order: Replication and Induction in Scientific Practice (London: Sage, 1985), Ch. 4.

7 Even in legal writings centrally concerned with the evaluation of testimony, the need to spell out the grounds of persons' differential credibility was apparently rarely felt; see, e.g., Shapiro, Probability and Certainty, pp. 179-188 (cit. n. 4); Julian Martin, “'Knowledge Is Power': Francis Bacon, the State and the Reform of Natural Philosophy" (Ph.D. diss., Univ. Cambridge, 1988), esp. Ch. 3; cf. Peter Dear, "Totius in verba: Rhetoric and Authority in the Early Royal Society," Isis, 1985, 76:145161 , on pp. 153-157.

${ }^{8}$ Robert Boyle, "An Hydrostatical Discourse, occasioned by the Objections of the Learned Dr. Henry More" (1672), in Boyle, Works, ed. Thomas Birch, 6 vols. (London, 1772) (hereafter Boyle, Works), Vol. III, pp. 596-628, on p. 626. In other circumstances Boyle elected to credit the testimony of divers: see Boyle, "Of the Temperature of the Submarine Regions," ibid., pp. 342-349, on p. 342; and Shapin and Schaffer, Leviathan and the Air-Pump (cit. n. 4), pp. 217-218.

${ }^{9}$ For the Coga episode, see The Correspondence of Henry Oldenburg, ed. A. Rupert Hall and Marie Boas Hall, 13 vols. (Madison: Univ. Wisconsin Press; London: Mansell/Taylor \& Francis, 1965-1986), Vol. III, pp. 611, 616-617; Vol. IV, pp. xx-xxi, 6, 59, 77; "An Account of the Experiment of Transfusion, practised upon a Man in London," Philosophical Transactions, 9 Dec. 1667, No. 30, pp. 557-559; Henry Stubbe, Legends No Histories (London, 1670), p. 179.
} 
witnessing might be mobilized around them. What sorts of places were available for this program? What conditions and opportunities did they provide? Put simply, the task resolves into the search for the actual sites of seventeenth-century English experiment. Where and what was the laboratory?

Two preliminary cautions are necessary. The first is a warning against verbal anachronism. The word laboratory (or elaboratory) was not in common English usage at the middle of the seventeenth century. For example, despite his extensive description of ideal experimental sites, I cannot find the word used by Francis Bacon, in The New Atlantis or elsewhere. As Owen Hannaway has shown, there is some evidence of medieval Latin usage (laboratorium), but the word did not acquire anything of its modern sense until the late sixteenth century. It seems that the word was transmitted into English usage in the late sixteenth century, carrying with it alchemical and chemical resonances. ${ }^{10}$ Among scores of English usages I have registered through the 1680s, I have not encountered one in which the space pointed to was one without a furnace, used as a nonportable source of heat for chemical or pharmaceutical operations. The word did become increasingly common during the course of the seventeenth century, although even by the early eighteenth century it was not used routinely to refer to just any place dedicated to experimental investigation. ${ }^{11}$ On the founding of the Royal Society there were a number of plans for purpose-built experimental sites, none of which materialized, even though the new Oxford Ashmolean $\mathrm{Mu}-$ seum (1683) did contain a chemical laboratory in its basement. ${ }^{12}$ By the end of the century there still did not exist any purpose-designed and purpose-built structure dedicated to those non-heat-dependent sciences (such as pneumatics and hydrostatics) that were paradigmatic of the experimental program. The new experimental science was carried on in existing spaces, used just as they were or modified for the purpose.

Second, the status of spaces designated as laboratories and of experimental venues generally in seventeenth-century England was intensely contested. Were they private or public, and what status ought they to have? In the rhetoric of

\footnotetext{
10 See Hannaway, "Laboratory Design" (cit. n. 1), pp. 585-586; and (on alchemical usage) Shapin and Schaffer, Leviathan and the Air-Pump, p. 57 and note. For reference to the "laboratory" as an intensely private space, see Gabriel Plattes, "Caveat for Alchymists," in Samuel Hartlib, comp., Chymical, Medicinal, and Chyrurgical Addresses (London, 1655), p. 87.

11 I shall use the term more loosely, although it should be clear from the context what sort of place is being referred to. Like Hannaway ("Laboratory Design," p. 585), I accept that an intensive investigation of scientific sites would be obliged to take in such places as the anatomical theater, the astronomical observatory, the curiosity cabinet, and the botanic garden.

12 For futile planning by the Royal Society in the late 1660 s to construct experimental facilities in the grounds of Arundel House, see Michael Hunter, "A 'College' for the Royal Society: The Abortive Plan of 1667-1668," Notes and Records of the Royal Society, 1983-1984, 38:159-186. Wren's plan (p. 173) called for "a fair Elaboratory" in the basement of the proposed house. Before the society was founded there were several proposals for experimental colleges which included laboratories: see [William Petty], The Advice of W.P. to Mr. Samuel Hartlib . . . (London, 1648; rpt. in The Harleian Miscellany, Vol. VI [London, 1745]), pp. 1-13 (pp. 5, 7 for the “Chymical Laboratory"); John Evelyn to Robert Boyle, 3 Sept. 1659, in The Diary and Correspondence of John Evelyn, ed. W. Bray, 3 vols. (London, 1852), Vol. III, pp. 116-120. A year after the society's foundation a plan emerged for a "Philosophical Colledge," again with "great Laboratories for Chymical Operations": Abraham Cowley, A Proposition for the Advancement of Experimental Philosophy (London, 1661), p. 25. For the Ashmolean laboratory, see R. F. Ovenell, The Ashmolean Museum 1683-1894 (Oxford: Clarendon Press, 1986), pp. 16-17, 22; and Edward Lhuyd to John Aubrey, 12 Feb. 1686, quoted in S. Mendyk, "Robert Plot: Britain's 'Genial Father of County Natural Histories,' " Notes Rec. Roy. Soc., 1985, 39:159-177, on p. 174 n. 28 (for confusion about what space was designated by "ye Labradory").
} 
English experimental philosophers, what was wrong with existing forms of practice was their privacy. Neither the individual philosopher in his study nor the solitary alchemist in his "dark and smokey" laboratory was a fit actor in a proper setting to produce objective knowledge (see Figure 1). ${ }^{13}$ In contrast, spaces appropriate to the new experimental program were to be public and easy of access. This was the condition for the production of reliable knowledge within. ${ }^{14}$ In stipulating that experiment was to take place in public spaces, experimental philosophers were describing the nature of the physical and social setting in which genuine knowledge might be made.

The performance and the consideration of experimental work in mid to late seventeenth-century England took place in a variety of venues. These sites ranged from the apothecary's and instrument maker's shop, to the coffeehouse, the royal palace, the rooms of college fellows, and associated collegiate and university structures. But by far the most significant venues were the private residences of gentlemen or, at any rate, sites where places of scientific work were coextensive with places of residence, whether owned or rented. The overwhelming majority of experimental trials, displays, and discussions that we know about occurred within private residences. Instances could be enumerated ad libitum: the laboratory equipped for Francis Mercury van Helmont at Anne Conway's Ragley House in Warwickshire; the role of Towneley House in Lancashire in the career of English pneumatics; Clodius's laboratory in the kitchen of his father-in-law Samuel Hartlib's house in Charing Cross; Kenelm Digby's house and laboratory in Covent Garden after the Restoration; the Hartlibian laboratory worked by Thomas Henshaw and Thomas Vaughan in their rooms at Kensington; William Petty's lodgings at Buckley Hall in Oxford, where the Experimental Philosophy Club originated in 1649; Thomas Willis's house, Beam Hall, where the club met during the early 1660 s. ${ }^{15}$

In the following sections of this paper I shall try to display the conditions and

${ }^{13}$ Robert Boyle, "The Sceptical Chymist," in Boyle, Works, Vol. I, pp. 458-586, on p. 461, intended to draw "the chymists' doctrine out of their dark and smokey laboratories" and bring "it into the open light." The contemporary Dutch-Flemish pictorial genre of "the alchemist in his laboratory" generally depicted alchemical workplaces in this way, without the necessary implication of criticism: see C. R. Hill, "The Iconography of the Laboratory," Ambix, 1975, 22:102-110; Jane P. Davidson, David Teniers the Younger (London: Thames \& Hudson, 1980), pp. 38-43; and Davidson, "I Am the Poison Dripping Dragon': Iguanas and Their Significance in the Alchemical and Occult Paintings of David Teniers the Younger," Ambix, 1987, 34:62-80 (who diverges from Hill in her acceptance that Teniers's many paintings of the laboratory genre are probably accurate and informed representations of such sites).

${ }_{14}$ Thus accusations that the Royal Society's meeting places were not public might count as particularly devastating: see, e.g., Thomas Hobbes, "Dialogus physicus de natura aeris" (1661), in Hobbes, Latin Works, ed. Sir William Molesworth, 5 vols. (London, 1839-1845), Vol. IV, pp. 233-296, on p. 240; Shapin and Schaffer, Leviathan and the Air-Pump (cit. n. 4), pp. 112-115, 350; and Stubbe, Legends No Histories (cit. n. 9), "Preface," sig. *3.

${ }^{15}$ Among secondary sources that are relatively rich in material relating to these sites, see Robert G. Frank, Jr., Harvey and the Oxford Physiologists: A Study of Scientific Ideas (Berkeley/Los Angeles: Univ. California Press, 1980), Ch. 3; Charles Webster, The Great Instauration: Science, Medicine and Reform 1626-1660 (London: Duckworth, 1975), esp. pp. 47-63, 89-98, 130-157; R. T. Gunther, Early Science in Oxford, 15 vols. (Oxford: privately printed, 1923-1967), Vol. I, pp. 7-51; Betty Jo Dobbs, "Studies in the Natural Philosophy of Sir Kenelm Digby," Parts I-III, Ambix, 1971, 18:1-20; 1973, 20:144-163; 1974, 21:1-28; Ronald Sterne Wilkinson, "The Hartlib Papers and Seventeenth-Century Chemistry, Part II," Ambix, 1970, 17:85-110; Lesley Murdin, Under Newton's Shadow: Astronomical Practices in the Seventeenth Century (Bristol: Adam Hilger, 1985); and Michael Hunter, Science and Society in Restoration England (Cambridge: Cambridge Univ. Press, 1981). 


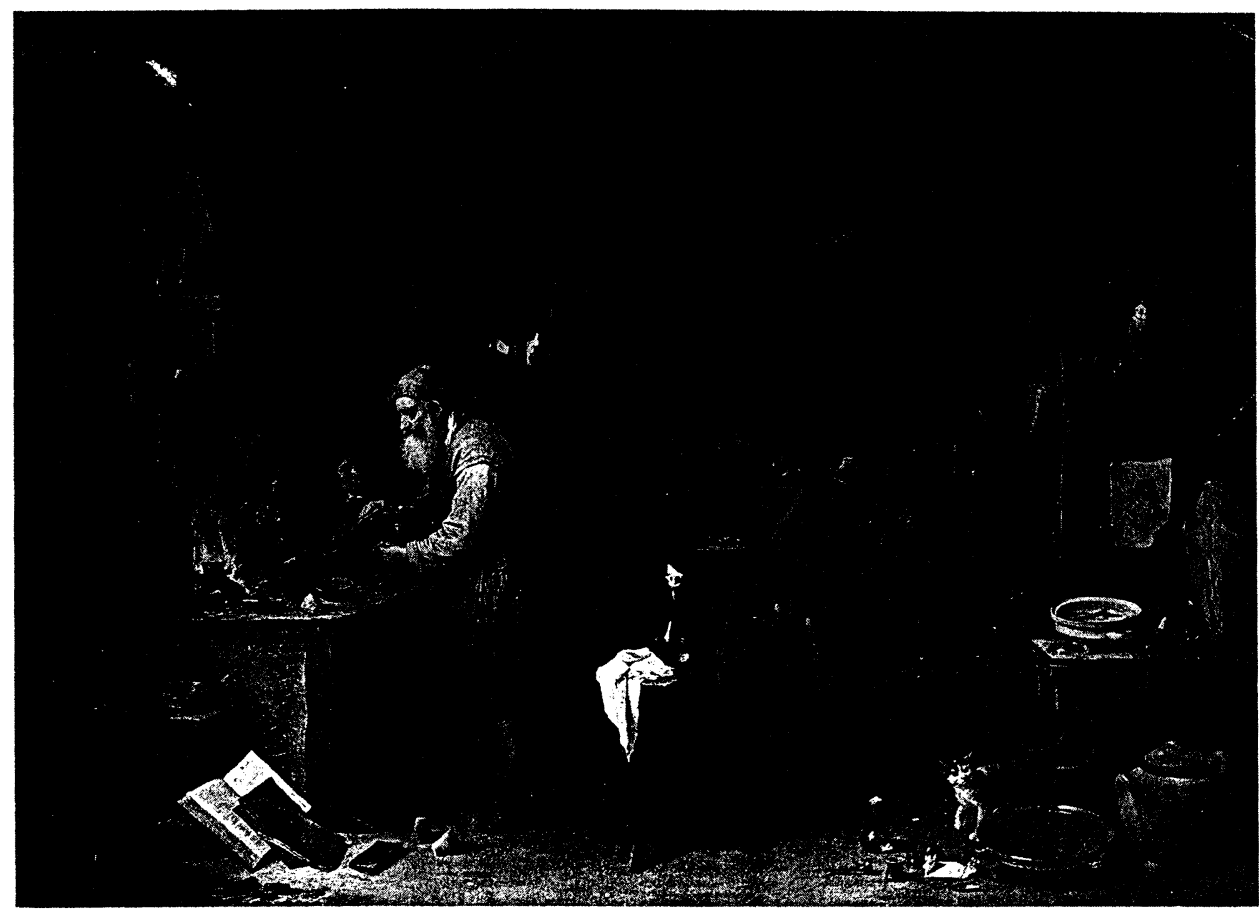

Figure 1. The Alchemist in His Laboratory; painting from about 1649 by David Teniers the Younger (1610-1690). This is typical of very many such paintings by Teniers and other Dutch and Flemish artists of the mid to late seventeenth century. Note particularly the presence of only one "master" in the scene, the fact that assistants are either clearly subservient or backgrounded, and the prominence of texts. Courtesy of the Philadelphia Museum of Art, John G. Johnson Collection.

opportunities presented by the siting of experiment in the private house. In particular, I shall point to the role of conditions regulating access to such venues and to conventions governing social relations within them. I will argue that these conditions and conventions counted toward practical solutions of the questions of how one produced experimental knowledge, how one evaluated experimental claims, and how one mobilized and made visible the morally adequate grounds for assenting to such claims. To this end I shall concentrate on three of the most important sites in the career of experiment in mid to late seventeenth-century England: the various residences and laboratories of Robert Boyle, the meeting places of the Royal Society of London, and the quarters occupied by Robert Hooke.

Robert Boyle. Boyle had laboratories at each of the three major residences he successively inhabited during his mature life. From about 1645 to about 1655 he was mainly in residence at the manor house of Stalbridge in Dorset, an estate acquired by his father, the first Earl of Cork, in 1636 and inherited by his youngest son on the earl's death in 1643. By early in 1647 Boyle was organizing a chemical laboratory at Stalbridge, perhaps with the advice of the Hartlibian circle, whose London laboratories he frequently visited. ${ }^{16}$ Late in 1655 or early in

\footnotetext{
${ }^{16}$ Robert Boyle to Lady Ranelagh, 6 Mar. 1647, in Boyle, Works, Vol. I, p. xxxvi, and Vol. VI, pp.
} 
1656 he removed to Oxford, where his sister Katherine, Lady Ranelagh, had searched out rooms for him in the house of the apothecary John Crosse, Deep Hall in the High Street. He was apparently able to use Crosse's chemical facilities, and his own rooms contained a pneumatic laboratory, where, assisted by Hooke, the first version of the air pump was constructed in 1658-1659. ${ }^{17}$ During his Oxford period Boyle also had access to a retreat at Stanton St. John, a village several miles to the northeast, where he made meteorological observations but apparently did not have a laboratory of any kind.

Boyle was away from Oxford for extended periods, staying sometimes at a house in Chelsea, sometimes with Katherine in London, and sometimes with another sister, Mary Rich, Countess of Warwick, at Leese (or Leighs) Priory in Essex. ${ }^{18}$ In 1666 he had Oldenburg look over possible lodgings in Newington, north of London, but there is no evidence that he ever occupied these. And he periodically stayed at Beaconsfield in Buckinghamshire, possibly at the home of the poet Edmund Waller. But Oxford remained his primary residence and experimental workplace until he moved into quarters with Katherine at her house in Pall Mall in 1668. This was a house (actually two houses knocked into one) assigned to Lady Ranelagh by the Earl of Warwick in 1664. It stood on the south side of Pall Mall, probably on the site now occupied by the Royal Automobile Club. Although luxury building in this area was proceeding apace in the Restoration, at the time Boyle moved in Pall Mall still retained a rather quiet and semirural atmosphere. During the 1670s Boyle's neighbors included Henry Oldenburg, Dr. Thomas Sydenham, and Nell Gwyn.

Boyle's laboratory in Katherine's house was probably either in the basement or attached to the back, and there is some evidence to suggest that one could obtain access to the laboratory from the street without passing through the rest of the house. ${ }^{19}$ The unmarried Boyle seems to have dined regularly with his sister, who was a major social and cultural figure in her own right, living "on the publickest scene," and who entertained his guests at the family table. ${ }^{20} \mathrm{He}$ remained there until his death in 1691 , which closely followed Katherine's.

39-40; G. Agricola to Boyle, 6 Apr. 1668, ibid., Vol. VI, pp. 650-651; and James Randall Jacob, "Robert Boyle, Young Theodicean" (Ph.D. diss., Cornell Univ., 1969), pp. 129-138. For the Stalbridge house, see R. E. W. Maddison, "Studies in the Life of Robert Boyle, F.R.S., Part VI: The Stalbridge Period, 1645-1655, and the Invisible College," Notes Rec. Roy. Soc., 1963, 18:104-124; Maddison, The Life of the Honourable Robert Boyle F.R.S. (London: Taylor \& Francis, 1969), Ch. 2; Nicholas Canny, The Upstart Earl: A Study of the Social and Mental World of Richard Boyle, First Earl of Cork 1566-1643 (Cambridge: Cambridge Univ. Press, 1982), pp. 68, 73, 98-99.

17 Lady Ranelagh to Boyle, 12 Oct. [1655], in Boyle, Works, Vol. VI, pp. 523-524; Maddison, Life of Boyle, Ch. 3.

${ }^{18}$ For Chelsea, see The Diary of John Evelyn, ed. E. S. de Beer (London: Oxford Univ. Press, 1959), pp. 410, 417; Henry Oldenburg to Robert Boyle, 10 Sept. 1666, in Oldenburg, Correspondence (cit. n. 9), Vol. III, pp. 226, 227n.; and Maddison, Life of Boyle (cit. n. 16), p. 94. For Leese, see Boyle to Oldenburg, 13 June 1666, in Oldenburg, Correspondence, Vol. III, p. 160; Mary Rich, Memoir of Lady Warwick: Also Her Diary, from A.D. 1666 to 1672 (London: Religious Tract Society, 1847?), esp. pp. 51, 161-163, 242-243; and Maddison, Life of Boyle, pp. 74, 132, 142.

19 Lady Ranelagh to Boyle, 13 Nov. [1666] (as given, but more likely to be 1667), in Boyle, Works, Vol. VI, pp. 530-531 (where Katherine offers her "back-house" to be converted into a laboratory); Thomas Birch, "Life of Boyle," ibid., Vol. I, pp. vi-clxxi, on pp. cxlv, cxxix; John Aubrey, Brief Lives, ed. Oliver Lawson Dick (Harmondsworth: Penguin, 1972), p. 198; and Maddison, Life of Boyle, pp. 128-129, 133-137, 177-178.

${ }_{20}$ Gilbert Burnet, Select Sermons ... and a Sermon at the Funeral of the Honourable Robert Boyle (Glasgow, 1742), pp. 204-205; Maddison, Life of Boyle, pp. 134-135; and Webster, Great Instauration, pp. 61-63. 
The Royal Society. After its founding in 1660, the weekly meetings of the Royal Society were held in Gresham College in Bishopsgate Street, originally in the rooms of the professor of geometry, afterward in rooms specially set aside for its use. The Great Fire of London in September 1666 made Gresham College unavailable, and temporary hospitality was extended by Henry Howard, later sixth Duke of Norfolk, at Arundel House, his residence in the Strand. The society met there for seven years, from 1667 to 1674 , until Gresham become available again (see Figures 2 and 3). Gresham continued to be its home until 1710, when the society for the first time became the owner of its premises, purchasing the former home of a physician, Crane Court in Fleet Street. ${ }^{21}$

During the 1660 s and 1670 s the society was continually searching for alternative accommodation and making plans, all of which proved abortive, for purpose-built quarters of its own. In the event, for the first half century of its existence the public business of the Royal Society was transacted largely within places of private residence. Arundel House was unambiguously such a place, and Gresham College, built in the late sixteenth century as the residence of the great merchant banker Sir Thomas Gresham and transformed into a place of public instruction in 1598, had by the 1660 s changed its character. When the Royal Society met there, it was a place where some professors lived and taught; where other sinecurist professors lived and did not teach; and where still others, who were not professors, lived in quarters hired out to them. According to its modern historian, Gresham College had by the mid 1670s "declined from a seat of learning into a lodging house." The significance of Arundel House in seventeenth-century English culture and social life cannot be overestimated. Until his death in 1646 it was the residence of Thomas Howard, second Earl of Arundel, who (despite the Catholicism he abandoned in 1616) as Earl Marshal was the head of the English nobility and the "custodian of honour." Arundel was one of the greatest collectors and patron of the arts of his age, and the house that contained his collections was made into a visible symbol of how a cultivated English gentleman ought to live. Indeed, his patronage of the educationalist Henry Peacham resulted in the production of an influential vade mecum for the guidance of English gentlemen. Arundel and his circle set themselves the task of modeling and exemplifying the code of English gentility, drawing liberally upon Italianate patterns. His grandson Henry Howard continued the great Arundel's proclivities, and it was through the encouragement of his friend John Evelyn that the society was offered space in the gallery of Arundel House and, ultimately, became one of the beneficiaries of the celebrated Arundel Collection of books, manuscripts, and objets d'art. ${ }^{22}$

${ }^{21}$ D. C. Martin, "Former Homes of the Royal Society," Notes Rec. Roy. Soc., 1967, 22:12-19; I. R. Adamson, "The Royal Society and Gresham College 1660-1711," Notes Rec. Roy. Soc., 1978-1979, 33:1-21; and Charles Richard Weld, A History of the Royal Society, 2 vols. (London, 1848), Vol. I, pp. 80-85, 192-198. For a satirical account of the Royal Society at Gresham, and esp. of the Repository and "the Elaboratory-keepers Apartment," see [Edward Ward], The London-Spy, 4th ed. (London, 1709), pp. 59-60.

22 Hunter, “A 'College' for the Royal Society" (cit. n. 12); and Adamson, "The Royal Society and Gresham College," pp. 5-6. For Arundel House see David Howarth, Lord Arundel and His Circle (New Haven, Conn.: Yale Univ. Press, 1985); and Graham Perry, The Golden Age Restor'd: The Culture of the Stuart Court, 1603-42 (Manchester: Manchester Univ. Press, 1981), Ch. 5. For Peacham see Henry Peacham, The Complete Gentleman . . . , ed. Virgil B. Heltzel (1622, 1634, 1661; Ithaca, N.Y.: Cornell Univ. Press, 1962), pp. ix-XX. 
Robert Hooke. On the founding of the Royal Society Robert Hooke was still serving Boyle as his technical assistant, lodging with Boyle in Oxford and when in London staying at least occasionally with Lady Ranelagh. When in November 1662 he was appointed by the society to the position of curator of experiments, Boyle was thanked "for dispensing with him for their use." By the next year Hooke was made a fellow (with charges waived) and was being paid by the society to lodge in Gresham College four days a week. ${ }^{23}$ In 1664 he was elected professor of geometry at Gresham, with its associated lodgings, and there he remained, even during the society's absence at Arundel House, until his death in 1703. His quarters apparently opened behind the college "reading hall" and contained an extensive pneumatical, mechanical, and optical workshop, supplemented in 1674 by a small astronomical observatory constructed in a turret over his lodgings. ${ }^{24}$

The conditions in which Hooke lived and worked were markedly different from those of his patron Robert Boyle. Margaret 'Espinasse has vividly described his personal life at Gresham, where he "lived like a rather Bohemian scientific fellow of a college." His niece Grace was sharing his quarters from 1672 (when she was eleven years old) and was evidently sharing his bed sometime afterward. Hooke was also having sexual relations with his housekeeper Nell Young and, on her departure, with her successors. To what extent Hooke's domestic circumstances were known to his associates among the fellowship is unclear, though it is possible that there was some connection between those circumstances and the relative privacy of his rooms. It was Hooke who visited his high-minded patron Boyle; Boyle almost never visited Hooke. Hooke's relations with his various technicians were, in a different way, also very intimate. He took several of them into his lodgings, where they were treated in a manner intermediate between sons and apprentices (three of them becoming fellows of the Royal Society and one succeeding him as curator). Although his rooms were rarely frequented by gentlemen fellows on other than scientific and technical matters, and although his table was not a major venue for their discourses, Hooke lived on a public stage. He circulated through the taverns and the coffeehouses of the City of London and was a fixture at the tables of others. Hooke's place of residence, probably the most important site for experimental trials of Restoration England, was in practice a private place, while he himself lived an intensely public life. It is questionable indeed whether Hooke's quarters constituted a "home" in seventeenth-century gentlemanly usage. It was a place fit for Hooke to live and to work; it was not a place fit for the reception and entertainment of gentlemen. ${ }^{25}$

${ }^{23}$ Thomas Birch, The History of the Royal Society of London, 4 vols. (London, 1756-1757), Vol. I, pp. 123-124, 250; and Oldenburg to Boyle, 10 June 1663, in Boyle, Works, Vol. VI, p. 147.

${ }^{24}$ Margaret 'Espinasse, Robert Hooke (London: Heinemann, 1956), pp. 4-5; John Ward, Lives of the Professors of Gresham College (London, 1740), pp. 91, 178; and Adamson, "The Royal Society and Gresham College" (cit. n. 21), p. 4. The contents of Hooke's rooms at his death in 1703 are detailed in Public Record Office (London) MS PROB 5/1324. I thank Dr. Michael Hunter for a transcript of this inventory, which he will shortly publish.

${ }_{25}$ 'Espinasse, Robert Hooke, pp. 106-107, 113-127, 131-138, 141-147. The major source for Hooke's domestic life and activities is his diary for periods from the early 1670s: The Diary of Robert Hooke, M.A., M.D., F.R.S., 1672-1680, ed. Henry W. Robinson and Walter Adams (London: Taylor \& Francis, 1935); and The Diary of Robert Hooke, Nov. 1688 to March 1690; Dec. 1692 to Aug. 1693, in Gunther, Early Science in Oxford (cit. n. 15), Vol. X, pp. 69-265. I have surveyed the diurnal 


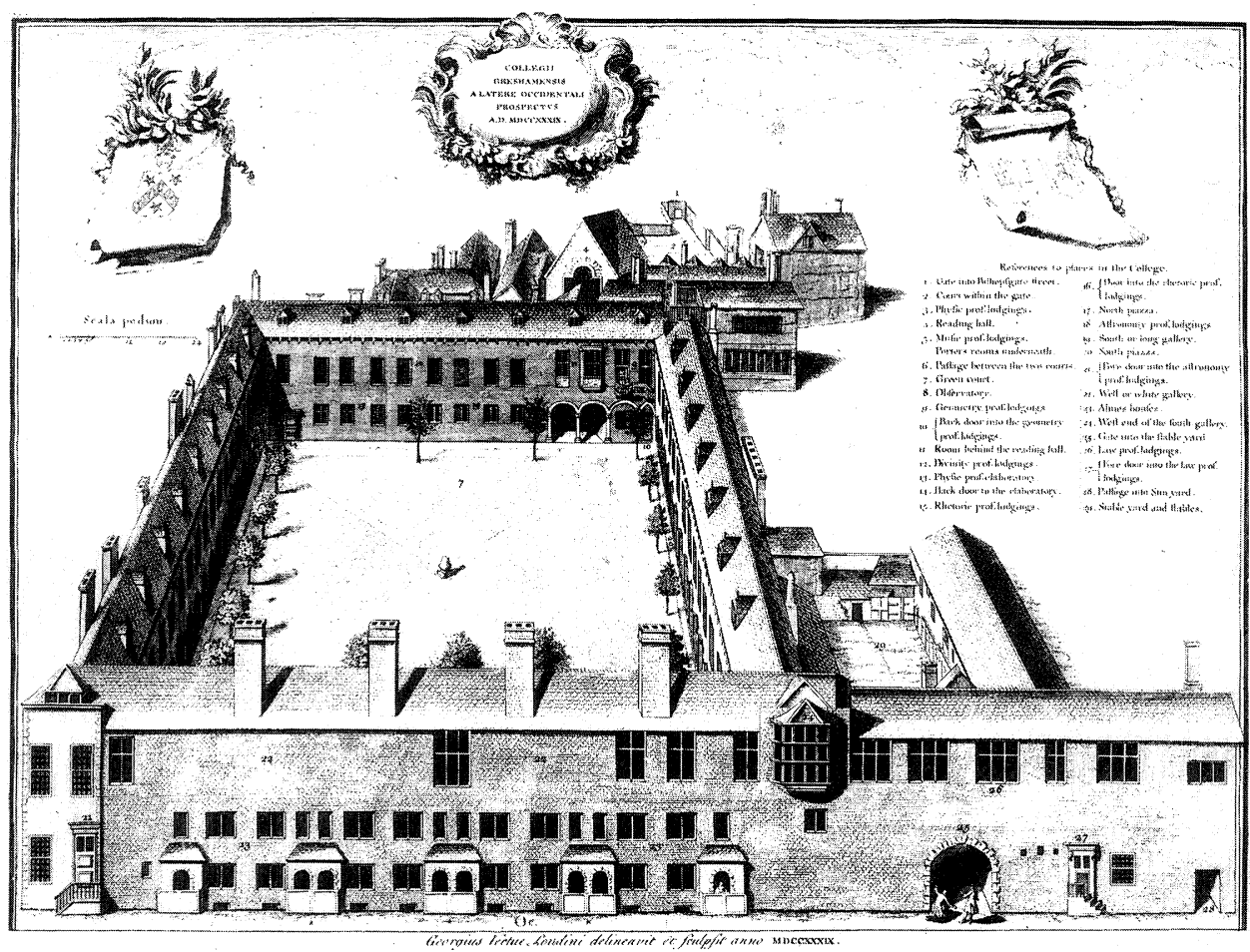

Figure 2. Gresham College in Bishopsgate Street, London; engraving from about 1739 by George Vertue. Gresham College was the meeting place of the Royal Society during 1660-1666 and 1674-1710. The lodgings of Robert Hooke, as professor of geometry, are at the far right corner of the quadrangle. Note also the turret above his rooms, used for astronomical observations. The Royal Society originally met in the rooms of the professor of astronomy at the near left corner of the quadrangle, later in various other rooms. The West Gallery where the Royal Society kept its Repository is in the foreground on the top floor. The college reading hall, where professors lectured, is the large pitched-roof structure behind Hooke's rooms. From John Ward, Lives of the Professors of Gresham College (London, 1740); courtesy of Special Collections, University of Edinburgh Library.

\section{ACCESS}

The threshold of the experimental laboratory was constructed out of stone and social convention. Conditions of access to the experimental laboratory would flow from decisions about what kind of place it was. In the middle of the century those decisions had not yet been made and institutionalized. Meanwhile there were a variety of stipulations about the functional and social status of spaces given over to experiment, and a variety of sentiments about access to them.

To the young Robert Boyle the threshold of his Stalbridge laboratory constituted the boundary between sacred and secular space. He told his sister Katherine that "Vulcan has so transported and bewitched me, that as the delights I taste

patterns of Hooke's life and tried to relate them to his place in the experimental community: Steven Shapin, "Who Was Robert Hooke?" in Robert Hooke: New Studies, ed. Michael Hunter and Simon Schaffer (Woodbridge, Suffolk: Boydell \& Brewer, forthcoming). An unreflectively Freudian account of Hooke's sex life is found in Lawrence Stone, The Family, Sex and Marriage in England 1500-1800 (London: Weidenfeld \& Nicolson, 1977), pp. 561-563. 
in it make me fancy my laboratory a kind of Elysium, so as if the threshold of it possessed the quality the poets ascribe to Lethe, their fictions made men taste of before their entrance into those seats of bliss, I there forget my standish [inkstand] and my books, and almost all things." ${ }^{26}$ The experimenter was to consider himself "honor'd with the Priesthood of so noble a Temple" as the "Commonwealth of Nature." And it was therefore fit that laboratory work be performed, like divine service, on Sundays. (In mature life Boyle entered his Pall Mall laboratory directly after his morning devotions, although he had apparently given up the practice of experimenting on the Sabbath.) ${ }^{27}$ In the 1640s he told his Hartlibian friends of his purposeful "retreat to this solitude" and of "my confinement to this melancholy solitude" in Dorset. But it was said to be a wished-for and a virtuous solitude, and Boyle complained bitterly of interruptions from visitors and their trivial discourses. ${ }^{28}$

Transactions across the experimental threshold had to be carefully managed. Solitude appeared both as a mundanely practical consideration and as a symbolic condition for the experimentalist to claim authenticity. Models of space in which solitude was legitimate and out of which valued knowledge emerged did exist: these included the monastic cell and the hermit's hut. The hermit's hut expressed and enabled individual confrontation with the divine; the solitude of the laboratory likewise defined the circumstances in which the new "priest of nature" might produce knowledge as certain and as morally valuable as that of the religious isolate. Here was a model of space perceived to be insulated from distraction, temptation, distortion, and convention. ${ }^{29}$ Yet experimentalists like Boyle and his Royal Society colleagues in the 1660 s were engaged in a vigorous attack on the privacy of existing forms of intellectual practice. The legitimacy of experimental knowledge, it was argued, depended upon a public presence at some crucial stage or stages of knowledge making. If experimental knowledge did indeed have to occupy private space during part of its career, then its realization as authentic knowledge involved its transit to and through a public space.

This transit was particularly difficult for a man in Boyle's position to accomplish and make visible as legitimate. He presented himself as an intensely private man, one who cared little for the distractions and rewards of ordinary social life. This presentation of self was successful. Bishop Burnet, who preached Boyle's funeral sermon, described him as a paragon: "He neglected his person, despised

26 Boyle to Lady Ranelagh, 31 Aug. 1649, in Boyle, Works, Vol. VI, pp. 49-50, and Vol. I, p. xlv; cf. Boyle to [Benjamin Worsley?], n.d. (probably late 1640s), ibid., Vol. VI, pp. 39-40.

${ }^{27}$ Boyle Papers, Royal Society (hereafter Boyle Papers), Vol. VIII, fol. 128, quoted in Jacob, "Boyle, Young Theodicean" (cit. n. 16), p. 158 (quotation). See also Harold Fisch, "The Scientist as Priest: A Note on Robert Boyle's Natural Theology," Isis, 1953, 44:252-265; Shapin and Schaffer, Leviathan and the Air-Pump (cit. n. 4), p. 319; and, on Sunday experiments, Jacob, "Boyle, Young Theodicean," pp. 153-154. In one of Boyle's later notebooks he recorded how many experiments he had performed day by day for periods between 1684 and 1688 . By then, the rule had clearly become "never on Sunday": Boyle Papers, Commonplace Book, 190, fols. 167-171. See also Maddison, Life of Boyle (cit. n. 16), p. 187; and Maddison, "Studies in the Life of Robert Boyle, F.R.S., Part IV: Robert Boyle and Some of His Foreign Visitors," Notes Rec. Roy. Soc., 1954, 11:38-53, on p. 38.

${ }^{28}$ Boyle to Benjamin Worsley, n.d., in Boyle, Works, Vol. VI, pp. 39-41; and Boyle to Lady Ranelagh, 13 Nov. ?, ibid., pp. 43-44. (Both letters probably date from the late 1640s.) See also Marie Boas, Robert Boyle and Seventeenth-Century Chemistry (Cambridge: Cambridge Univ. Press, 1958), pp. 15-16, 19, 21.

${ }^{29}$ Note the monastic flavor of the Cowley, Evelyn, and Petty plans for philosophical colleges. Evelyn's referred explicitly to a Carthusian model: Evelyn, Diary and Correspondence (cit. n. 12), Vol. III, p. 118. 

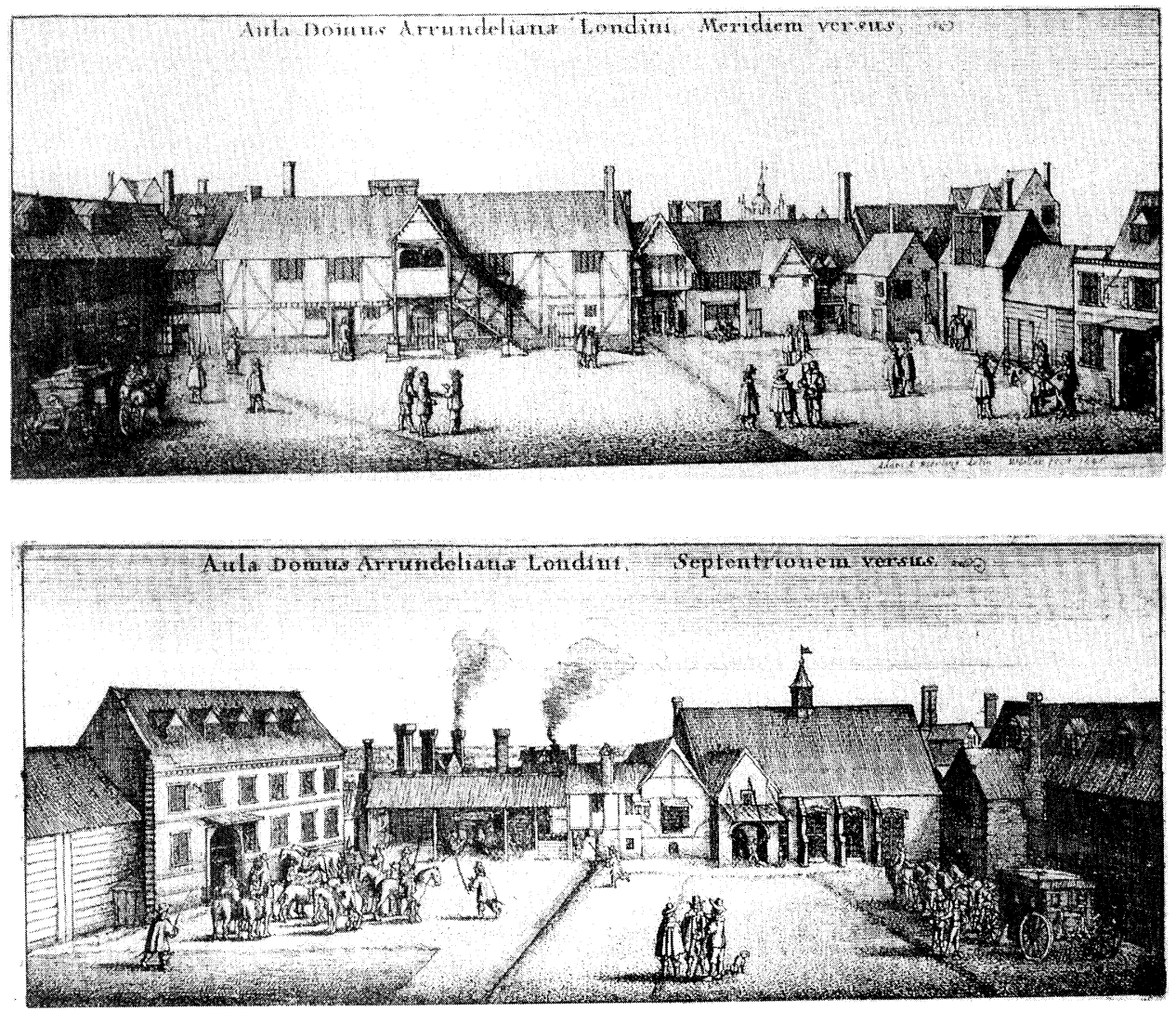

Figure 3. Arundel House in the Strand, London; engraving from about 1646 by Wenceslaus Hollar. Arundel House was the meeting place of the Royal Society during 1667-1674 and London home of the Howards, Earls of Arundel and Dukes of Norfolk. Arundel House began to be pulled down from 1678. From Arthur M. Hind, Wenceslaus Hollar and His Views of London and Windsor in the Seventeenth Century (London, 1922).

the world, and lived abstracted from all pleasures, designs, and interests." 30 At the same time, Boyle effectively secured the persona of a man to whom justified access was freely available. He was entitled by birth and by wealth (even as diminished by the Irish wars) to a public life, and, indeed, there were forces that acted to ensure that he did live in the public realm. He advertised the public status of experimental work and, from his first publication, condemned unwarranted secrecy and intellectual unsociability. ${ }^{31}$ Yet he chose much solitude, was seen to do so, and was drawn only fitfully into the company of fellow Christian virtuosi, extended exposure to which drove him once more to solitude. In constructing his life and making it morally legitimate Boyle was endeavoring to

${ }^{30}$ Gilbert Burnet, History of His Own Time, 6 vols. (Oxford: Oxford Univ. Press, 1833), Vol. I, p. 351; cf. Burnet, Select Sermons (cit. n. 20), pp. 202, 210: Boyle "had neither designs nor passions."

31 [Robert Boyle], "An Epistolical Discourse of Philaretus to Empiricus, ... inviting All True Lovers of Vertue and Mankind, to a Free and Generous Communication of Their Secrets and Receits in Physick" (prob. written 1647), in Hartlib, comp., Chymical, Medicinal, and Chyrurgical Addresses (cit. n. 10), pp. 113-150, rpt. in Margaret E. Rowbottom, "The Earliest Published Writing of Robert Boyle," Annals of Science, 1948-1950, 6:376-389, on pp. 380-385. 
define the nature of a space in which experimental work might be practically situated and in which experimental knowledge would be seen as authentic. Such a space did not then clearly exist. The conditions of access to it and the form of social relations within it had to be determined and justified. This space had necessarily to be carved out of and rearranged from existing domains of accepted public and private activity and existing stipulations about the proper uses of spaces.

Many contemporary commentators remarked upon the ease of access to Boyle's laboratory. John Aubrey wrote about Boyle's "noble laboratory" at Lady Ranelagh's house as a major object of intellectual pilgrimage: "When foreigners come to hither, 'tis one of their curiosities to make him a Visit." This was the laboratory that was said to be "constantly open to the Curious, whom he permitted to see most of his Processes." In 1668 Lorenzo Magalotti, emissary of the Florentine experimentalists, traveled especially to Oxford to see Boyle and boasted that he was rewarded with "about ten hours" of his discourse, "spread over two occasions." John Evelyn noted that Boyle "had so universal an esteeme in Foraine parts; that not any Stranger of note or quality; Learn'd or Curious coming into England, but us'd to Visite him." He "was seldome without company" in the afternoons, after his laboratory work was finished..$^{32}$

But the strain of maintaining quarters "constantly open to the curious" told upon him and was seen to do so. As an overwrought young man he besought "deare Philosophy" to "come quickly \& releive Your Distresst Client" of the "vaine Company" that forms a "perfect Tryall of my Patience." Experimental philosophy might rescue him "from some strange, hasty, Anchoritish Vow"; it could save him from his natural "Hermit's Aversenesse to Society." 33 When, during the plague, members of the Royal Society descended upon him in Oxford, he bolted for the solitude of his village retreat at Stanton St. John, complaining of "ye great Concourse of strangers," while assuring Oldenburg that "I am not here soe neere a Hermite" but that some visitors were still welcome. Even as John Evelyn praised Boyle's accessibility, he recorded that the crowding "was sometimes so incomodious that he now and then repair'd to a private Lodging in another quarter [of London], and at other times" to Leese or elsewhere in the country "among his noble relations." 34

\footnotetext{
32 On foreigners: Aubrey, Brief Lives (cit. n. 19), p. 198; Eustace Budgell, Memoirs of the Lives and Characters of the Illustrious Family of the Boyles, 3rd ed. (London, 1737), p. 144; R. E. W. Maddison, "Studies in the Life of Robert Boyle, F.R.S., Part I: Robert Boyle and Some of His Foreign Visitors," Notes Rec. Roy. Soc., 1951, 9:1-35, on p. 3; Birch, "Life of Boyle" (cit. n. 19), p. cxlv. For Magalotti: W. E. Knowles Middleton, "Some Italian Visitors to the Early Royal Society," Notes Rec. Roy. Soc., 1978-1979, 33:157-173, on p. 163; Lorenzo Magalotti at the Court of Charles II: His "Relazione d'Inghilterra" of 1668, ed. and trans. Middleton (Waterloo, Ontario: Wilfrid Laurier Univ. Press, 1980), p. 8. Similar hospitality was extended in 1669, when Magalotti escorted the Grand Duke of Tuscany to Boyle's Pall Mall laboratory: [Lorenzo Magalotti], Travels of Cosmo the Third, Grand Duke of Tuscany (London, 1821), pp. 291-293; and R. W. Waller, "Lorenzo Magalotti in England 1668-1669," Italian Studies, 1937, 1:49-66. For Evelyn's comments: John Evelyn to William Wotton, 29 Mar. 1696, quoted in Maddison, "Studies in the Life of Boyle, Part IV" (cit. n. 27), p. 38.

33 Boyle Papers, Vol. XXXVII, fol. 166 (no date but probably mid to late 1640s). For background to this manuscript ("The Gentleman"), see J. R. Jacob, Robert Boyle and the English Revolution: A Study in Social and Intellectual Change (New York: Burt Franklin, 1977), pp. 48-49.

34 Boyle to Oldenburg, 8, c. 16 and 30 Sept. and 9 Dec. 1665; Oldenburg to Spinoza, 12 Oct. 1665; Sir Robert Moray to Oldenburg, 4 Dec. 1665, in Oldenburg, Correspondence (cit. n. 9), Vol. II, pp. $502,509,537,563,568,627,639$; and Evelyn to Wotton, 29 Mar. 1696, quoted in Maddison, "Studies in the Life of Boyle, Part IV," p. 38; and Maddison, Life of Boyle (cit. n. 16), pp. 186-188.
} 
Toward the end of his life Boyle took drastic and highly visible steps to restrict access to his drawing room and laboratory. It is reported that when he was at work trying experiments in the Pall Mall laboratory and did not wish to be interrupted, he caused a sign to be posted on his door: "Mr. Boyle cannot be spoken with to-day." In his last years and in declining health, he issued a special public advertisement "to those of his ffriends \& Acquaintance, that are wont to do him the honour \& favour of visiting him," to the effect that he desired "to be excus'd from receiving visits" except at stated times, "(unless upon occasions very extraordinary)." 35 Bishop Burnet said that Boyle "felt his easiness of access" made "great wasts on his time," but "thought his obligation to strangers was more than bare civility." 36

That obligation was a powerful constraint. The forces that acted to keep Boyle's door ajar were social forces. Boyle was a gentleman as well as an experimental philosopher. Indeed, as a young man he had reflected systematically upon the code of the gentleman and his own position in that code. The place where Boyle worked was also the residence of the son of the first Earl of Cork. It was a point of honor that the private residence of a gentleman should be open to the legitimate visits of other gentlemen. Seventeenth-century handbooks on the code of gentility stressed this openness of access: one such text noted that "Hospitalitie" was "one of the apparentest Signalls of Gentrie." Modern historians confirm the equation between easy access and gentlemanly standing: "generous hospitality was the hallmark of a gentleman"; "so long as the habit of open hospitality persisted, privacy was unobtainable, and indeed unheard of." And as the young Boyle himself confided in his Commonplace Book, a "Noble Descent" gives "the Gentleman a Free Admittance into many Companys, whence Inferior Persons (tho never so Deserving) are . . . excluded." ${ }^{37}$ Other gentlemen knew who was a gentleman, they knew the code regulating access to his residence, and they knew that Boyle was obliged to operate under this code. But they did not know, nor could they, what an experimental scientist was, nor what might be the nature of a different code governing admittance to his laboratory. In the event, as Marie Boas wrote, they might plausibly come to the conclusion that Boyle "was only a virtuoso, amusing himself with science, [that] he could be interrupted at any time. . . . There was always a swarm of idle gentlemen and ladies who wanted to see amusing and curious experiments." 38 When, however, Boyle wished to shut his door to these distractions, he was able to draw upon widely understood moral patterns that enabled others to recognize what he was doing and why it might be

35 On the sign: Weld, History of the Royal Society (cit. n. 21), Vol. I, p. 136n; Maddison, Life of Boyle, pp. 177-178; cf. Diary of Hooke, in Gunther, Early Science in Oxford (cit. n. 15), Vol. X, p. 139 (entry for 29 July 1689): “To Mr. Boyle. Not to be spoken wth." For the advertisement: Boyle Papers, Vol. XXXV, fol. 194. There are a number of other drafts of this advertisement in the Boyle Papers; one is printed in Maddison, Life of Boyle, p. 177.

${ }^{36}$ Burnet, Select Sermons (cit. n. 20), p. 201; Maddison, "Studies in the Life of Boyle, Part I" (cit. n. 32), pp. 2-3.

${ }^{37}$ Richard Brathwait, The English Gentleman (London, 1630), pp. 65-66, sig. Nnn2r; Lawrence Stone and Jeanne C. Fawtier Stone, An Open Elite? England 1540-1880 (Oxford: Clarendon Press, 1984), pp. 307-310; and Boyle Papers, Vol. XXXVII, fol. 160v.

38 Boas, Boyle and Seventeenth-Century Chemistry (cit. n. 28), p. 207. On the role of the virtuoso and the expectation that his collections would be accessible to the visits of others, see Walter E. Houghton, Jr., "The English Virtuoso in the Seventeenth Century," Journal of the History of Ideas, 1942, 3:51-73, 190-219; and Oliver Impey and Arthur MacGregor, eds., The Origins of Museums: The Cabinet of Curiosities in Sixteenth- and Seventeenth-Century Europe (Oxford: Clarendon Press, 1985). 
legitimate. The occasional privacy of laboratory work could be assimilated to the morally warrantable solitude characteristic of the religious isolate. ${ }^{39}$

\section{RIGHTS OF PASSAGE}

What were the formal conditions of entry to experimental spaces? We do have some information concerning the policy of the early Royal Society, particularly regarding access of English philosophers to foreign venues. It was evidently common for the society's council to give "intelligent persons, whether Fellows of the Society or not, what are styled 'Letters Recommendatory.' "These documents, in Latin, requested "that all persons in authority abroad would kindly receive the bearer, who was desirous of cultivating science, and show him any attention in their power." 40 Similarly, in 1663 the society drafted a statute regulating access to its own meetings. As soon as the president took the chair, "those persons that [were] not of the society, [were to] withdraw." There was, however, an exemption for certain classes of persons to remain if they chose, that is, "for any of his majesty's subjects . . . having the title and place of a baron, or any of his majesty's privy council . . . , or for any foreigner of eminent repute, with the allowance of the president." Other persons might be permitted to stay with the explicit consent of the president and fellows in attendance. Barons and higherranking aristocrats could become fellows on application, without the display of philosophical credentials. ${ }^{41}$

Too much should not be made of such fragmentary evidence of formal conditions granting or withholding rights of entry to experimental sites. It is noteworthy how sparse such evidence is, even for a legally incorporated body like the Royal Society. In the main, the management of access to experimental spaces, even those of constituted organizations, was effected more informally. For example, there was the letter of introduction to an experimentalist, a number of which survive. In 1685 one visitor carried with him a letter of introduction, from someone presumably known to Boyle, which identified the bearer as "ambitious to be known to you, whose just character of merit is above his quality . . . , being the eldest son of [a diplomat] and brother-in-law to the king of Denmark's envoy." 42 In this instance and in others like it, it was not stated that the proposed entrant to Boyle's society possessed any particular technical competences, nor even that he was "one of the curious," merely that he was a gentleman of quality and merit, as

39 There was, of course, another model available in principle to identify the conditions of privacy. This was the alchemist's laboratory, but Boyle worked hard to discredit that model, even as he spent time in the relatively open laboratories of the Hartlib circle. See, e.g., Samuel Hartlib to Boyle, 28 Feb. 1654 and 14 Sept. 1658, in Boyle, Works, Vol. VI, pp. 78-83, 114-115.

40 Weld, History of the Royal Society (cit. n. 21), Vol. I, pp. 224-225.

${ }^{41}$ Birch, History of the Royal Society (cit. n. 23), Vol. I, pp. 264-265. On the society's increasing concern for secrecy and the limitation of public access in the 1670s, see Michael Hunter and Paul B. Wood, "Towards Solomon's House: Rival Strategies for Reforming the Early Royal Society," History of Science, 1986, 24:49-108, on pp. 74-75. The test for admittance to fellowship of a special claim to scientific knowledge was not formalized until 1730: Maurice Crosland, "Explicit Qualifications as a Criterion for Membership of the Royal Society: A Historical Review," Notes Rec. Roy. Soc., 1983, 37:167-187.

${ }^{42}$ Joseph Hill to Boyle, 20 Apr. 1685, in Boyle, Works, Vol. VI, p. 661. At about the same time, an eminent cleric wrote announcing his imminent visit but assured the weary Boyle that it would be sufficient to have "some servant of yours" delegated "to shew me your laboratory": Bishop of Cork to Boyle, 12 June 1683, ibid., p. 615. 
vouched for by the correspondent. In other cases, "curiosity" was explicitly stipulated as a sufficient criterion for entry.

Generally speaking, it appears that access to most experimental venues (and especially those located in private residences) was achieved in a highly informal manner, through the tacit system of recognitions, rights, and expectations that operated in the wider society of gentlemen. If we consider Boyle's laboratories and drawing rooms, it seems that entry was attained if one of three conditions could be met: if the applicant was (1) known to Boyle by sight and of a standing that would ordinarily give rights of access; (2) known to Boyle by legitimate reputation; (3) known to Boyle neither by sight nor by reputation, but arriving with (or with an introduction from) someone who satisfied condition (1) or (2). These criteria can be expressed much more concisely: access to experimental spaces was managed by calling upon the same sorts of conventions that regulated entry to gentlemen's houses, and the relevant rooms within them, in general. ${ }^{43}$ These criteria were not codified and written down because they did not need to be. They would be known and worked with by every gentleman. Indeed, they would almost certainly be known and worked with by those who were not gentlemen, shaping their understanding of the grounds for denying entry. Standing gave access. Boyle was perhaps unusual among English gentlemen in reflecting explicitly upon this largely tacit knowledge: "A man of meane Extraction (tho never so advantag'd by Greate meritts) is seldome admitted to the Privacy \& the secrets of greate ones promiscuously \& scarce dares pretend to it, for feare of being censur'd saucy, or an Intruder." 44

I have alluded to some formal criteria governing entry to the rooms of the Royal Society. For all the significance of such considerations, informal criteria operated there as well, just as they did in the case of Boyle's laboratories, to manage passage across the society's threshold. These almost certainly encompassed not only the informal criteria mentioned in connection with Boyle, for whom standing gave access, but also other sorts of tacit criteria. When Lorenzo Magalotti visited England in 1668 (after the Royal Society's removal to Arundel House), his arrival at the society's weekly meeting was apparently expected and special experiments had been made ready to be shown. But Magalotti had second thoughts about the advisability of attending and the terms on which he thought entry was offered. "I understood," he wrote to an Italian prelate, "that one is not permitted to go in simply as a curious passer-by, [and] I would not agree to take my place there as a scholar, for one thing because I am not one. . . Thus,

\footnotetext{
${ }^{43}$ One would like to know much more about the specific sites within the house where experimental work was done and where experimental discourses were held. In addition to rooms designated for public use, the closet, where many virtuosi kept their curiosities (including scientific instruments) and where intimate conversations often took place, should be of particular interest. The closet was a room variously located and variously employed in the seventeenth century, but many examples were situated off the bedroom, meaning that this was a private space, access to which acknowledged or accorded intimacy. For the closet and divisions of domestic space generally, see Mark Girouard, Life in the English Country House: A Social and Architectural History (Harmondsworth: Penguin, 1980), esp. pp. 129-130; and Gervase Jackson-Stops and James Pipkin, The English Country House: A Grand Tour (London: Weidenfeld \& Nicolson, 1985), Ch. 9. For an analysis of the internal layout of the house in relation to social structure, see Norbert Elias, The Court Society, trans. Edmund Jephcott (Oxford: Basil Blackwell, 1983), Ch. 3.

44 Robert Boyle, "An Account of Philaretus [i.e., Mr. R. Boyle] during His Minority," in Boyle, Works, Vol. I, pp. xii-xxvi, on p. xiii.
} 
therefore, I got as far as the door and then went away, and if they do not want to permit me to go and be a mere spectator without being obliged to give opinions like all the others, I shall certainly be without the desire to do so." 45 There are reasons to doubt the absolute reliability of Magalotti's testimony. Nevertheless, he pointed to a crucially important tacit criterion of entry. Magalotti was, of course, the sort of person, carrying the sort of credentials, who would have had unquestioned access to the Royal Society meeting at Arundel House, or, indeed to Arundel House itself. His claims indicate, however, that the experimental activities that went on within its interior imposed further informal criteria regulating entry. These included the uncodified expectation that, once admitted, one would act as a participant. The notion of participation followed from a distinction, customary, but not absolute, between spectating and witnessing. The Royal Society expected those in attendance to validate experimental knowledge as participants, by giving witness to matters of fact, rather than to play the role of passive spectators to the doings of others. ${ }^{46}$ But there was a further consideration: those granted entry were tacitly enjoined to employ the conventions of deportment and discourse deemed appropriate to the experimental enterprise, rather than those current in, say, hermetic, metaphysical, or rationalist practice. Those unwilling to observe these conventions could exclude themselves. These are the grounds on which one might rightly say that a philosopher like Thomas Hobbes was, in fact, excluded from the precincts of the Royal Society, even though there is no evidence that he sought entry and was turned away. 'Espinasse was therefore quite correct in saying that the society was "open to all classes rather in the same way as the law-courts and the Ritz," and Quentin Skinner was also right to characterize it as "like a gentlemen's club," even if he unnecessarily contrasted that status with the society's ostensible role as "the conscious centre of all genuinely scientific endeavour." 47

\section{RELATIONS IN PUBLIC}

If we are able to recognize what kind of space we are in, we find we already possess implicit knowledge of how it is customary to behave there. But in the middle of the seventeenth century the experimental laboratory and the places of experimental discourse did not have standard designations, nor did people who found themselves within them have any tacit knowledge of the behavioral norms obtaining there. On the one hand, publicists of the experimental program offered detailed guidance on the social relations deemed appropriate to experimental spaces; on the other, there is virtual silence about some of the most basic fea-

\footnotetext{
${ }^{45}$ Lorenzo Magalotti to Cardinal Leopold, 14 Feb. 1668, in Middleton, "Some Italian Visitors to the Royal Society," p. 160; Waller, "Magalotti in England," pp. 52-53; and Magalotti at the Court of Charles II, ed. and trans. Middleton, p. 8 (all cit. n. 32).

${ }^{46}$ For divergences of opinion among the fellowship about whether or not mere spectators ought to be encouraged, see Hunter and Wood, "Towards Solomon's House," p. 71, 87-92. Hooke took a particularly strong line that participants only were wanted; see also Philosophical Experiments and Observations of the Late Eminent Dr. Robert Hooke, ed. W. Derham (London, 1726), pp. 26-27.

${ }^{47}$ Margaret 'Espinasse, "The Decline and Fall of Restoration Science," Past and Present, 1958, 14:71-89, on p. 86; and Quentin Skinner, "Thomas Hobbes and the Nature of the Early Royal Society," Historical Journal, 1969, 12:217-239, on p. 238. See also Michael Hunter, The Royal Society and Its Fellows 1660-1700: The Morphology of an Early Scientific Institution (Chalfont St. Giles, Bucks.: British Society for the History of Science, 1982), p. 8. On Hobbes and the Royal Society see Shapin and Schaffer, Leviathan and the Air-Pump (cit. n. 4), pp. 131-139.
} 
tures of these places. The situation is about what one would expect if new patterns of behavior in one domain were being put together out of patterns current in others.

In 1663 the Royal Society was visited by two Frenchmen, Samuel Sorbière, physician and informal emissary of the Montmor Academy, and the young Lyonnaise scholar Balthasar de Monconys. Both subsequently published fairly detailed accounts of the society's procedures. Sorbière recorded that the meeting room at Gresham was some sort of "Amphitheatre," possibly the college reading hall or an adaptation of a living room of Gresham's sixteenth-century cloistered house to make it suitable for public lecturing. The president sat at the center of a head table, with the secretary at his side and chairs for distinguished visitors. The ordinary fellows sat themselves on plain wooden benches arranged in tiers, "as they think fit, and without any Ceremony." 48 An account dating from around 1707 , toward the end of the society's stay at Gresham, gives a description of three rooms in which it conducted its affairs but omits any detail of the internal arrangements or of social relations within them. ${ }^{49}$

When Magalotti visited the Royal Society at Arundel House in February 1668, he described the assembly room off the gallery, "in the middle of which is a large round table surrounded by two rows of seats, and nearer to it by a circle of plush stools for strangers." On his second visit in April 1669 he recorded that the president sat "on a seat in the middle of the table of the assembly." 50 No visitor, or any other commentator, provides a detailed account of the physical and social arrangements attending the performance of experiments in the Royal Society. Monconys offers a recitation of experiments done, without describing the circumstances in which they were done. Sorbière mentions only that there was brief discussion of "the Experiments proposed by the Secretary." Magalotti records that he saw experiments performed, demonstrated by "a certain Mr Hooke."

48 Samuel Sorbière, A Voyage to England, containing Many Things relating to the State of Learning, Religion, and Other Curiosities of that Kingdom (London: 1709; trans. of 1664 French original), pp. 35-38; and Journal des voyages de Monsieur de Monconys (Lyons, 1666), separately paginated "Seconde Partie: Voyage d'Angleterre," p. 26. See also Thomas Molyneux to William Molyneux, 26 May 1683, in K. Theodore Hoppen, "The Royal Society and Ireland: William Molyneux, F.R.S. (1656-1698)," Notes Rec. Roy. Soc., 1963, 18:125-135, on p. 126; and Maddison, "Studies in the Life of Boyle, Part I" (cit. n. 32), pp. 14-21. There is a brief "official" account of the society's rooms in Thomas Sprat, History of the Royal Society (London, 1667), p. 93.

49 Account of the Proceedings in the Council of the Royal Society, in Order to Remove from Gresham College (London, 1707?), partly rpt. in Weld, History of the Royal Society, Vol. I, pp. 82-83; and Martin, "Former Homes of the Royal Society" p. 13 (both cit. n. 21). A brief account of the society's rooms in the last year of its occupancy of Gresham College is in London in 1710: From the Travels of Zacharias Conrad von Uffenbach, trans. and ed. W. H. Quarrell and Margaret Mare (London: Faber \& Faber, 1934), pp. 97-102. Uffenbach described the "wretchedly ordered" repository and library, and the "very small and wretched" room where the society usually met. At that time it was sparsely decorated with portraits of its members (including, Uffenbach claimed, a picture of Hooke, about which he was mistaken or which was subsequently lost), two globes, a model of a contrivance for rowing, and a large pendulum clock. There is no pictorial record of an internal space occupied by the Royal Society in the seventeenth century. For an engraving (of doubtful date) recording a Crane Court meeting see T. E. Allibone, The Royal Society and Its Dining Clubs (Oxford: Pergamon Press, 1976), frontispiece.

${ }_{50}$ Magalotti to Cardinal Leopold, 21 Feb. 1668, in Middleton, "Some Italian Visitors to the Royal Society," pp. 160-161; and Magalotti, Travels of Cosmo, pp. 185-186 (both cit. n. 32). Too much weight should not, perhaps, be given to Magalotti's evidence. He seems to have been confused about where exactly he was: in the 1669 account he says that he went with the Grand Duke "to Arundel House, in the interior of Gresham College." Moreover, he seems to have derived portions of his version of the society from Sorbière's earlier account. 
These were set up on a table in the corner of the meeting room at Arundel House. When working properly, experiments were transferred to a table in the middle of the room and displayed, "each by its inventor." Experimental discussion then ensued. ${ }^{51}$ By the 1670 s it is evident that experimental "discourse," or formal presentation setting forth and interpreting experiments tried elsewhere, was much more central to the society's affairs than experiments tried and displayed within its precincts.

Sorbière, Monconys, Magalotti, and other observers all stressed the civility of the Royal Society's proceedings. The president, "qui est toujours une personne de condition," was clearly treated with considerable deference, by virtue of his character, his office, and, most important, his function in guaranteeing good order. Patterns provided by procedure in the House of Commons are evident. Fellows addressed their speech to the president, and not to other fellows, just as members of the House of Commons conventionally addressed the Speaker. Thus, the convenient fiction was maintained that it was always the matter and not the man that was being addressed. Both Sorbière and Magalotti noted that fellows removed their hats when speaking, as a sign of respect to the president (again following Commons practice). Whoever was speaking was never interrupted, "and Differences of Opinion cause no manner of Resentment, nor as much as a disobliging Way of Speech." 52 An English observer said that the society "lay aside all set Speeches and Eloquent Haranques (as fit to be banisht out of all Civil Assemblies, as a thing found by woful experience, especially in England, fatal to Peace and good Manners)," just as the reading of prepared speeches was (and is) conventionally deprecated in Commons. "Opposite opinions" could be maintained without "obstinacy," but with good temper and "the language of civility and moderation." 53

This decorum was the more remarkable in that it was freely entered into and freely sustained. Sorbière said that "it cannot be discerned that any Authority prevails here"; and Magalotti noted that at "their meetings, no precedence or distinction of place is observed, except by the president and the secretary." As in the seventeenth-century House of Commons, the practice of taking any available seat (with the exception of the president and the secretaries, who, like the Commons Speaker, his clerks, and privy councillors, sat at the head of the room) constituted a visible symbol of the equality in principle of all fellows and of the absence of sects, even if the reality, in both houses, might be otherwise ${ }^{54}$ All

\footnotetext{
51 Journal des voyages de Monconys (cit. n. 48), pp. 26-28, 47, 55-57; Sorbière, Voyage to England (cit. n. 48), p. 37; Maddison, "Studies in the Life of Boyle, Part I" (cit. n. 32), pp. 16-19 (Monconys), 21 (Sorbière); and Magalotti to Cardinal Leopold, 21 Feb. 1668, in Middleton, "Some Italian Visitors to the Royal Society" (cit. n. 32), pp. 161-162.

52 Journal des voyages de Monconys, p. 26 (quoted); Magalotti, Travels of Cosmo, pp. 186-187; and Sorbière, Voyage to England, pp. 36-37. For Commons practice, see Sir Thomas Smith, De republica anglorum (London, ca. 1600), pp. 51-52. (This practice differs from that of the House of Lords, where speakers address "My lords.")

53 On set speeches: Edward Chamberlayne, Angliae notitia: or the Present State of England (7th ed., London, 1673), p. 345. Cf. Sir Thomas Erskine May, A Treatise on the Law, Privileges, Proceedings and Usage of Parliament, ed. T. Lonsdale Webster and William Edward Grey, 11th ed. (London: William Clowes \& Sons, 1906), pp. 310, 314-315, 344-345; and Lord Campion, An Introduction to the Procedure of the House of Commons (London: Macmillan, 1958), pp. 190, 192. On "opposite opinions": Magalotti, Travels of Cosmo, pp. 187-188. Cf. J. E. Neale, The Elizabethan House of Commons (London: Jonathan Cape, 1949), pp. 404-407; and Smith, De republica anglorum (cit. n. $52)$, p. 52. (Needless to say, these were stipulations of ideal behavior: violations of the norms in Commons were frequent.)

${ }^{54}$ Sorbière, Voyage to England, p. 38; and Magalotti, Travels of Cosmo, p. 187. Cf. George Henry
} 
visitors found it worth recording that the society's mace, laid on the table before the president when the meetings were convened, was an emblem of the source of order. Again, as in Commons, the mace indicated that the ultimate source was royal. The king gave the society its original mace even as he replaced the Commons mace that had disappeared in the Interregnum. The display of the mace in the Royal Society confirmed that its authority flowed from, and was of the same quality as, that of the king. Nevertheless, Thomas Sprat took violent exception to any notion that mace ceremonials constituted rituals of authority: "The Royal Society itself is so careful that such ceremonies should be just no more than what are necessary to avoid Confusion." 55 Sprat took the view that the space occupied and defined by the fellowship was truly novel: it was regulated by no traditional set of rituals, customs, or conventions. An anonymous fellow writing in the 1670s agreed: the society's job was "not to whiten the walls of an old house, but to build a new one; or at least, to enlarge the old, \& really to mend its faults."56

Yet no type of building, no type of society is wholly new. And despite the protestations of early publicists, it is evident that the social relations and patterns of discourse obtaining within the rooms of the Royal Society were rearrangements and revaluations of existing models. Aspects of a parliamentary pattern have already been mentioned. The relationship between the proceedings of the early Royal Society and the Interregnum London coffeehouse merits extended discussion, most particularly in connection with the rules of good order in a mixed assembly. Other elements resonate of the monastery, the workshop, the club, the college, and the army. ${ }^{57}$ Yet the most potent model for the society's social relations was drawn from the type of space in which they actually occurred. The code which is closest to that prescribed for the experimental discourses of the Royal Society was that which operated within the public rooms of a gentleman's private house.

\section{THE EXPERIMENTAL PUBLIC}

What was the experimental public like? How many people, and what sorts of people, composed that public? In order to answer these questions we have to

Jennings, comp., An Anecdotal History of the British Parliament . . . (London: Horace, Cox, 1880), p. 433; Vernon F. Snow, Parliament in Elizabethan England: John Hooker's Order and Usage (New Haven, Conn.: Yale Univ. Press, 1977), p. 164; and Neale, Elizabethan House of Commons (cit. n. 53), p. 364.

55 Journal des voyages de Monconys, p. 26; Sorbière, Voyage to England, p. 36; Magalotti, Travels of Cosmo, p. 186; Thomas Sprat, Observations on Mons. de Sorbière's Voyage into England (1665; London, 1708), pp. 164-165; Sprat, History of the Royal Society (cit. n. 48), p. 94. For the Commons mace: Erskine May, Usage of Parliament, p. 155; Campion, Procedure of Commons, pp. 54, 73; and for the society's mace: Margery Purver, The Royal Society: Concept and Creation (London: Routledge \& Kegan Paul, 1967), p. 140.

56 Quoted in Hunter and Wood, "Towards Solomon's House" (cit. n. 41), p. 81. The same author described the council as "the Societys Parliament" (pp. 68, 83).

57 The directed coordination of the society's labors prompted Robert Hooke to compare it to "a Cortesian army well Disciplined and regulated though their number be but small" (quoted in Hunter and Wood, “Towards Solomon's House," p. 87). On coffeehouses see, e.g., Aytoun Ellis, The Penny Universities: A History of the Coffee-Houses (London: Secker \& Warburg, 1956), esp. pp. 46-47 on rules of order. The Royal Society "club" of the 1670 s held much of its conversation in City coffeehouses like Garraway's and Jonathan's. On occasion, experimental performances were even staged at coffeehouses. For the connections between the late-Interregnum Harringtonian Rota club, meeting at Miles's coffeehouse, and the early Royal Society, see Anna M. Strumia, "Vita istituzionale della Royal Society seicentesca in alcuni studi recenti," Rivista Storica Italiana, 1986, 98:500-523, on pp. 520-523. (I owe this reference to Michael Hunter.) 
distinguish rhetoric from reality. When, for example, Sprat referred to the Royal Society's experimental public as being made up of "the concurring Testimonies of threescore or an hundred" and pointed to "many sincere witnesses standing by" experimental performances, he was, it seems, referring to an ideal state. The Royal Society was, of course, the most populated experimental space of Restoration England, but its effective attendance at weekly meetings probably averaged no more than two score, and by the 1670s meetings were being canceled for lack of attendance. ${ }^{58}$ More intimate groups assembled as "clubs" of the society, centered particularly upon Hooke and usually meeting at coffeehouses near Gresham College.

In the event, historians have rightly questioned whether the rooms of the Royal Society should properly be regarded as a major experimental site. ${ }^{59}$ Most actual experimental research was performed elsewhere, most notably in private residences like Boyle's Oxford and Pall Mall laboratories and in Hooke's quarters. Unsurprisingly, evidence about the population in these places is scarce. Boyle frequently named his experimental witnesses, and in no case does that named number exceed three. We do also have commentators' testimony about the throngs of visitors, but these are probably best regarded as genuine spectators rather than witnesses. ${ }^{60}$ I shall mention the circumstances of experimental work in Hooke's lodgings later, but his laboratory was certainly more thinly populated than that of his patron. Apart from Hooke himself, the population of Hooke's laboratory seems mainly to have been composed of his various assistants, technicians, and domestics.

I need in this connection to make a distinction between a real and a relevant experimental public, between the population actually present at experimental scenes and those whose attendance was deemed by authors to be germane to the making of knowledge. We have, for example, conclusive evidence of the presence in Boyle's laboratories of technicians and assistants of various sorts. As we might say, their role was vital, since Boyle himself had little if anything to do with the physical manipulation of experimental apparatus, and since at least several of these technicians were far more than mere laborers. ${ }^{61}$ Yet their presence was scarcely acknowledged in the scenes over which Boyle presided. Two of them, Hooke and Denis Papin, were named and responsible elements in those scenes, although even here Boyle's account probably understates their contribution. Toward the end of his career, Boyle acknowledged Papin's responsibility for the writing of experimental narratives as well as for the physical conduct of air-pump trials. "I had," he wrote, "cause enough to trust his skill and dili-

\footnotetext{
58 Sprat, History of the Royal Society, pp. 73, 100; and, on attendance, Hunter, The Royal Society and Its Fellows (cit. n. 47), pp. 16-19; and J. L. Heilbron, Physics at the Royal Society during Newton's Presidency (Los Angeles: William Andrews Clark Memorial Library, 1983), p. 4.

59 Hunter, Science and Society in Restoration England (cit. n. 15), p. 46.

60 The only record of a crowd scene in one of Boyle's laboratories is an account of the visit in 1677 of the German chemist Johann Daniel Kraft, when the display of phosphorus attracted "the confused curiosity of many spectators in a narrow compass." However, "no strangers were present" when the secret of the phosphorus was later revealed: Robert Hooke, Lectures and Collections made by Robert Hooke . . . (London, 1678), pp. 273-282; see also J. V. Golinski, "A Noble Spectacle: Research on Phosphorus and the Public Culture of Science in the Early Royal Society," Isis, 1989.

${ }^{61}$ I have prepared an extended study of the role and identity of technicians in seventeenth-century England; see also R. E. W. Maddison, "Studies in the Life of Robert Boyle, F.R.S., Part V: Boyle's Operator: Ambrose Godfrey Hanckwitz, F.R.S.," Notes Rec. Roy. Soc., 1955, 11:159-188 (see p. 159 for a partial list of Boyle's technicians).
} 
gence." But Boyle still insisted on his own ultimate responsibility for the knowledge produced, and the manner in which he did so is instructive: Boyle asked Papin to "set down in writing all the experiments and the phaenomena arising therefrom, as if they had been made and observed by his own skill. . . . But I, myself, was always present at the making of the chief experiments, and also at some of those of an inferior sort, to observe whether all things were done according to my mind." Certain interpretations of experiments were indeed left to Papin: "Some few of these inferences owe themselves more to my assistant than to me."62 Still, Boyle, not Papin, was the author of this text.

For the most part, however, Boyle's host of "laborants," "operators," "assistants," and "chemical servants" were invisible actors. They were not a part of the relevant experimental public. They made the machines work, but they could not make knowledge. Indeed, their greatest visibility (albeit still anonymous) derived from the capacity of their lack of skill to sabotage experimental operations. Time after time in Boyle's texts, technicians appear as sources of trouble. They are the unnamed ones responsible for pumps exploding, materials being impure, glasses not being ground correctly, machines lacking the required integrity. ${ }^{63}$

Technicians had skill but lacked the qualifications to make knowledge. This is why they were rarely part of the relevant experimental public, and when they were part of that public, it was because they were only ambiguously functioning in the role of technician. Ultimately, their absence from the relevant experimental public derived from their formal position in scenes presided over by others. Boyle's technicians, including those of mixed status like Hooke and Papin, were paid by him to do jobs of experimental work, just as both were paid to do similar tasks by the gentlemen of the Royal Society. As Boyle noted in connection with his disinclination to become a cleric, those that were paid to do something were open to the charge that this was why they did it. ${ }^{64}$ A gentleman's word might be relied upon partly because what he said was without consideration of remuneration. Free verbal action, such as giving testimony, was credible by virtue of its freedom. Technicians, as such, lacked that circumstance of credibility. Thus, so far as their capacity to give authentic experimental testimony was concerned, they were truly not present in experimental scenes. Technicians were not there in roughly the same way, and for roughly the same reasons, that allowed Victorian families to speak in front of the servants. It did not matter that the servants might hear: if they told what they heard to other servants, it did not signify; and if they told it to gentlemen, it would not be credited.

\section{THE CONDITION OF GENTLEMEN}

The early Royal Society set itself the task of putting together, justifying, and maintaining a relevant public for experiment. Its publicist Thomas Sprat reflected

62 Robert Boyle, "A Continuation of New Experiments Physico-Mechanical, touching the Spring and Weight of the Air ... The Second Part" (1680), in Boyle, Works, Vol. IV, pp. 505-593, on pp. 506-507.

63 Among very many examples, see esp. a note on the ineptitude of John Mayow (identified only by his initials): Robert Boyle, "A Continuation of New Experiments Physico-Mechanical touching the Spring and Weight of the Air" (1669), in Boyle, Works, Vol. III, pp. 175-276, on p. 187.

64 Burnet, Select Sermons (cit. n. 20), p. 200; Birch, "Life of Boyle" (cit. n. 19), p. 1x: "The irreligious fortified themselves against all that was said by the clergy, with this, that it was their trade, and that they were paid for it." 
at length on the social composition of this public and its bearing on the integrity of knowledge-making practices. Historians are now thoroughly familiar with the Royal Society's early insistence that its company was made up of "many eminent men of all Qualities," that it celebrated its social diversity, and that it pointed to the necessary participation in the experimental program of "vulgar hands." Nevertheless, this same society deemed it essential that "the farr greater Number are Gentlemen, free, and unconfin'd." In the view of Sprat and his associates the condition of gentlemen was the condition for the reliability and objectivity of experimental knowledge. ${ }^{65}$

There were two major reasons for this. First, an undue proportion of merchants in the society might translate into a search for present profit at the expense of luciferous experimentation and even into an insistence upon trade secrecy, both of which would distort the search for knowledge. This is what Glanvill meant in praising the society for its freedom from "sordid Interests." 66 More important, the form of the social relations of an assembly composed of unfree men, or, worse, a society divided between free and unfree, would corrupt the processes by which experimental knowledge ought to be made and evaluated, and by which that knowledge might be advertised as reliable. Unfree men were those who lacked discretionary control of their own actions. Technicians, for example, belonged to this class-the class of servants-because their scientific labor was paid for. Merchants might be regarded as compromised in that their actions were geared to achieving the end of present profit. One could not be sure that their word corresponded to their state of belief. Put merchants and servants in an assembly with gentlemen and you would achieve certain definite advantages. But there was also a risk in the shape of the knowledge-making social relations that might be released. Inequalities of rank could, in Sprat's view, corrode the basis of free collective judgment on which the experimental program relied. ${ }^{67}$

As Sprat said, the trouble with existing intellectual communities was the master-servant relationship upon which their knowledge-constituting practices were founded, the scheme by which "Philosophers have bin always Masters, \& Scholars; some imposing, \& all the other submitting; and not as equal observers without dependence." He judged that "very mischievous . . . consequences" had resulted because "the Seats of Knowledg, have been for the most part hereto-

${ }^{65}$ Sprat, History of the Royal Society (cit. n. 48), pp. 63-67, 76, 407, 427, 431, 435; also Robert Hooke, Micrographia (London, 1665), "Preface," sig. g1v. For visitors' accounts of social diversity in the society, see, e.g., Magalotti, Travels of Cosmo (cit. n. 32), pp. 186-188; Sorbière, Voyage to England (cit. n. 48), p. 37.

66 Joseph Glanvill, Scepsis scientifica (London, 1665), "Preface," sig. c1r; also sig. b4v for "a Society of persons that can command both Wit and Fortune." Peter Dear rightly notes evidence that the testimony of "lowly folk" might be credible because their accounts were less likely than those of the educated to be colored by theoretical commitments. This view was, however, rarely expressed and, as Dear says, was more than counterbalanced by the consideration that "gentlemen were trustworthy just because they were gentlemen": Dear, "Totius in verba" (cit. n. 7), pp. 156-157, emphasis in original.

${ }^{67}$ Sprat, History of the Royal Society (cit. n. 48), pp. 65-67. On seventeenth-century English thought about the master-servant relationship and the political significance of servitude, see C. B. Macpherson, The Political Theory of Possessive Individualism: Hobbes to Locke (Oxford: Oxford Univ. Press, 1970), esp. Ch. 3; Christopher Hill, "Pottage for Freeborn Englishmen: Attitudes to Wage-Labour," in Hill, Change and Continuity in Seventeenth-Century England (Cambridge, Mass.: Harvard Univ. Press, 1975), Ch. 10. 
fore, not Laboratories, as they ought to be; but onely Scholes, where some have taught, and all the rest subscrib'd." Thus the schoolroom was a useful resource in modeling a proper experimental space, precisely because it exemplified those conventional social relations deemed grossly inappropriate to the new practice: "The very inequality of the Titles of Teachers, and Scholars, does very much suppress, and tame mens Spirits; which though it should be proper for Discipline and Education; yet it is by no means consistent with a free Philosophical Consultation. It is undoubtedly true; that scarce any man's mind, is so capable of thinking strongly, in the presence of one, whom he fears and reverences; as he is, when that restraint is taken off." 68

The solution to the practical problem thus resolved into the description and construction of a social space that was both free and disciplined. Sprat said that the "cure" for the disease afflicting current systems of knowledge "must be no other, than to form an Assembly at one time, whose privileges shall be the same; whose gain shall be in common; whose Members were not brought up at the feet of each other." Such disinterested free men, freely mobilizing themselves around experimental phenomena and creating the witnessed matter of fact, could form an intellectual polity "upon whose labours, mankind might . . . freely rely."69 The social space that Sprat was attempting to describe was a composite of a number of existing and past spaces, real and ideal. Still, one model for such a space was, perhaps, more pertinent than any other, precisely because, as I have shown, it corresponded to the type of space within which experimental discourses typically occurred. This was the gentleman's private residence and, within it, its public rooms. The conventions regulating discourse in the drawing room were readily available for the construction of the new space and for making morally visible the social relations appropriate to it. It was the acknowledged freedom of the gentleman's action, the honor accorded to his word, the moral discipline he imposed upon himself, and the presumed moral equality of the company of gentlemen that guaranteed the reliability of experimental knowledge. In other words, gentlemen in, genuine knowledge out.

Gentlemen were bound to credit the word of their fellows or, at least, to refrain from publicly discrediting it. ${ }^{70}$ These expectations and obligations were grounded in the face-to-face relations obtaining in concrete spaces. The obligation to tell the truth, like the consequences of questioning that one was being told the truth, were intensified when one looked the other "in the face," and particularly when it was done in the public rooms of the other's house. The disastrous effects of violating this code were visible to the Royal Society in the quarrel between Gilles

68 Sprat, History of the Royal Society, pp. 67-69. Cf. John Webster, Academiarum examen (London, 1654), p. 106, where it is recommended that youth be educated "so they may not be sayers, but doers, not idle spectators, but painful operators; . . . which can never come to pass, unless they have Laboratories as well as Libraries, and work in the fire, better than build Castles in the air."

${ }^{69}$ Sprat, History of the Royal Society, p. 70. On fellows' freedom of judgment: Lotte Mulligan and Glenn Mulligan, "Reconstructing Restoration Science: Styles of Leadership and Social Composition of the Early Royal Society," Social Studies of Science, 1981, 11:327-364, on p. 330 (quoting William Croone); on the moral economy of the experimental community generally: Shapin and Schaffer, Leviathan and the Air-Pump (cit. n. 4), pp. 310-319, 332-344; and for Hobbes's suggestion that the Royal Society did indeed have "masters": ibid., pp. 112-115. On the presumed equality of all gentlemen: J. C. D. Clark, English Society 1688-1832: Ideology, Social Structure and Political Practice during the Ancien Regime (Cambridge: Cambridge Univ. Press, 1985), p. 103.

70 See, e.g., Peacham, The Complete Gentleman (cit. n. 22), p. 24; and Brathwait, The English Gentleman (cit. n. 37), pp. 83-84. 
Roberval and Henri-Louis Habert de Montmor in the latter's Parisian town house. As Ismael Boulliau told the story to Christiaan Huygens, Roberval

has done a very stupid thing in the house of M. de Montmor who is as you know a man of honor and position; he was so uncivil as to say to him in his own house ...., that he had more wit than he, and that he was less only in worldly goods. . . . Monsieur de Montmor, who is very circumspect, said to him that he could and should behave more civilly than to quarrel with him and treat him with contempt in his own house.

Roberval never returned to the Montmor Academy, and the group never recovered. The Parisians tried to learn a lesson: as this dispute was over doctrine, they resolved to move "towards the study of nature and inventions," in which civility could be more easily maintained since the price of dissenting publicly from a gentleman's testimony on matters of fact would dissuade others from the contest. $^{71}$

The code relating to face-to-face interactions in the house could be, and was, extended to the social relations of experimental knowledge production generally. It was rare indeed for any gentleman's testimony on a matter of experimental fact to be gainsaid. In the early 1670s Henry More disputed Boyle's report of a hydrostatical matter of fact. The manner of Boyle's response is telling: "Though [More] was too civil to give me, in terminus, the lye; yet he did indeed deny the matter of fact to be true. Which I cannot easily think, the experiment having been tried both before our whole society, and very critically, by its royal founder, his majesty himself." 72 Boyle appealed to the honor of a company of gentlemen, and, ultimately, to the greatest gentleman of all. In 1667 Oldenburg specifically cautioned fellows not to deny within the society's rooms experimental testimony deriving from foreign philosophers. Oldenburg took an offending fellow aside afterward and asked him "how he would resent it, if he should communicate upon his own knowledge an unusual experiment to [those foreign experimenters], and they brand it in public with the mark of falsehood: that such expressions in so public a place, and in so mixed an assembly, would certainly prove very destructive to all philosophical commerce." 73

The same relationship of trust that was enjoined to govern experimental discourse in the drawing room was constiıutive of transactions between public and private rooms of the experimental house. I noted at the beginning the central problem posed in empiricist practice by the indispensable role of testimony and trust. The Royal Society was evidently quite aware that the population of direct witnesses to experimental trials in the laboratory was limited by practical considerations if by nothing else. Nevertheless, the trajectory of a successful candidate for the status of matter of fact necessarily transited the public spaces in which it

\footnotetext{
71 Ismael Boulliau to Christiaan Huygens, 6 Dec. 1658, in Harcourt Brown, Scientific Organizations in Seventeenth Century France (1620-1680) (Baltimore: Williams \& Wilkins, 1934), pp. 87-89; see also pp. 108, 119, 126-127 (on civility), and p. 96 (for Oldenburg's familiarity with proceedings at Montmor's house).

72 Boyle, "Hydrostatical Discourse" (cit. n. 8), p. 615. For this episode, and for Boyle-More relations generally, see Shapin and Schaffer, Leviathan and the Air-Pump, pp. 207-224.

73 The episode concerned reports by physicians in Danzig regarding the transfusion of animal blood into humans: see Oldenburg to Boyle, 10 Dec. 1667, in Boyle, Works, Vol. VI, pp. 254-255; and Oldenburg, Correspondence (cit. n. 9), Vol. IV, pp. 26-28.
} 
was validated. The practical solution offered by the society was the acceptance of a division of experimental labor and the protection of a relationship of trust between those within and without the laboratory threshold. Sprat said that there was a natural division of labor among the fellowship: "Those that have the best faculty of Experimenting, are commonly most averse from reading Books; and so it is fit, that this Defect should be supply'd by others pains." Those that actually performed experimental trials, and those that accompanied them as direct witnesses, were neressarily few in number, but they acted as representatives of all the rest. One could, and ought to, trust them in the way one could trust the evidence of one's own senses: "Those, to whom the conduct of the Experiment is committed ... . do (as it were) carry the eyes, and the imaginations of the whole company into the Laboratory with them." Their testimony of what had been done and found out in the laboratory, undoubted because of their condition and quality, formed the basis of the assembly's discursive work, "which is to judg, and resolve upon the matter of Fact," sometimes accompanied by a showing of the experiment tried in the laboratory, sometimes on the basis of narrative alone. Only when there was clear agreement ("the concurring Testimonies") was a matter of fact established. Such procedures were advertised as morally infallible. Glanvill reckoned that "the relations of your Tryals may be received as undoubted Records of certain events, and as securely be depended on, as the Propositions of Euclide." The very transition from private to public space that marked the passage from opinion to knowledge was a remedy for endemic tendencies to "over-hasty" causal conjecturing, to "finishing the roof, before the foundation has been well laid." Sprat assured his readers that "though the Experiment was but the private task of one or two, or some such small number; yet the conjecturing, and debating on its consequences, was still the employment of their full, and solemn Assemblies."74 An item of experimental knowledge was not finished until it had, literally, come out into society.

\section{TRYING IT AT HOME}

A house contains many types of functionally differentiated rooms, each with its conditions of access and conventions of appropriate conduct within. Social life within the house involves a circulation from one sort of room to another. The career of experimental knowledge is predicated upon the same sort of circulation. Thus far I have spoken of the making of experimental knowledge in a loose way, scarcely differentiating between its production and its evaluation. I must now deal more systematically with the stages of knowledge making and relate these to the physical and social spaces in which they take place.

In mid to late seventeenth-century England there was a linguistic distinction the force and sense of which seem to have escaped most historians of science. This was the discrimination between "trying" an experiment, "showing" it, and "discoursing" upon it. In the common usage of the main experimental actors of this setting, the distinction between these terms was both routine and rigorous. The trying of an experiment corresponds to research proper, getting the thing to work, possibly attended with uncertainty about what constitutes a working

\footnotetext{
${ }^{74}$ Sprat, History of the Royal Society (cit. n. 48), pp. 97-102; Glanvill, Scepsis scientifica (cit. n. 66), "Preface," sig. c1r.
} 
experiment. Showing is the display to others of a working experiment, what is commonly called demonstration. ${ }^{75}$ And experimental discourses are the range of expatiatory and interpretative verbal behaviors that either accompany experimental shows or refer to shows or trials done at some other time or place. I want to say that trying was an activity that in practice occurred within relatively private spaces, whereas showing and discoursing were events in relatively public space. The career of experimental knowledge is the circulation between private and public spaces. ${ }^{76}$

We can get a purchase upon this notion by considering a day in the experimental life of Robert Hooke. I have noted that Hooke lived where he worked, in rooms at Gresham College with an adjacent laboratory, rooms that were little visited by fellow experimentalists, English or foreign. He rose and then dined early; usually at home and frequently with his technicians, some of whom lodged with him. Before issuing forth, Hooke worked at home, trying experiments, as his diary records: "tryd experiment of fire," or "tryd experiment of gunpowder." Some of these, Hooke noted, were preparations for displays at the Royal Society, either next door or, during the Arundel House period, a mile and a half away. It was in the assembly rooms of the society that these experiments were to be shown and discoursed on: "tryd expt of penetration of Liquors . . . shewd it at Arundell house." Experimental discourses could also take place elsewhere. When Hooke left his rooms, he would invariably resort to the local coffeehouses or taverns, where he would expect to meet a small number of serious and competent philosophers for experimental discussion. In the evenings he was a fixture at the tables of distinguished fellows of the society, notably at Boyle's, Christopher Wren's, and Lord William Brouncker's houses, where further experimental discourse occurred. ${ }^{77}$

Kuhn has written about what he sees as a crucial difference between the role of experiment in mid seventeenth-century England and preceding practices. In the experimental program of Boyle, Hooke, and their associates, Kuhn says, experiments were seldom performed "to demonstrate what was already known. . . . Rather they wished to see how nature would behave under previously unobserved, often previously nonexistent, circumstances."78 Broadly speaking, the point is a legitimate one. However, it applies only to one stage of

\footnotetext{
75 There are judicial resonances here, but they should not be overemphasized. What was most often being "tried" in experiment was some hypothesis or other explanatory item. In law the trial is of matter of fact, and the jury's judgment is of what counts as fact. However, the best parallel is between the experimental show and the "show trial," where the matter of fact is known (or decided upon) in advance. Both bear the same relation to their respective genuine trials. For the judicial process of "bringing matters to a trial," see Martin, "'Knowledge Is Power" " (cit. n. 7), Ch. 3.

${ }^{76}$ In this connection see David Gooding's excellent work on Faraday at the Royal Institution. Gooding studies the passage from the basement laboratory to the ground floor lecture theater as movement in the epistemological status of experimental phenomena: Gooding, "In Nature's School': Faraday as an Experimentalist," in Gooding and Frank A. L. James, eds., Faraday Rediscovered: Essays on the Life and Work of Michael Faraday, 1791-1867 (Basingstoke: Macmillan, 1985), pp. 106-135. See also H. M. Collins, "Public Experiments and Displays of Virtuosity: The Core-Set Revisited," Soc. Stud. Sci., 1988, 18 (in press).

${ }_{77}$ 'Espinasse, Robert Hooke (cit. n. 24), pp. 106-147; and Shapin, "Who Was Robert Hooke?" (cit. n. 25). The quotations, instances of which could be multiplied indefinitely, are from Hooke's 1672-1680 Diary (cit. n. 25), pp. 15, 37.

${ }_{78}$ Thomas S. Kuhn, "Mathematical versus Experimental Traditions in the Development of Physical Science," in Kuhn, The Essential Tension: Selected Studies in Scientific Tradition and Change (Chicago: Univ. Chicago Press, 1977), pp. 31-65, on p. 43.
} 
experimentation and to one site at which experimental activity occurs. Hooke and Boyle might, indeed, undertake experimental trials without substantial foreknowledge of their outcome, although they could scarcely have done so without any foreknowledge, since they would then have been unable to distinguish between experimental success and failure. An experimental trial could fail; indeed, trials usually did fail, in the sense that an outcome was achieved out of which the desired sense could not be made. Thus, Hooke's diary records, among many other instances: "Made tryall of Speculum. not good"; "Made tryall upon Speculum it succeeded not"; "at home all day trying the fire expt but could not make it succeed." So far as trials are concerned, a failure might legitimately be attributed to one or more of a number of causes: the experimenter was inept or blundered in some way; the equipment was defective or the materials impure; relevant background circumstances, not specifiable or controllable at the time of trial, were unpropitious, and so on. ${ }^{79}$ However, a further possibility was open and, indeed, sometimes considered by experimenters, namely that the theory, hypothesis, or perspective that informed one's sense of what counted as a successful outcome was itself incorrect. In a trial it was therefore always possible that an outcome deemed unsuccessful might come to be regarded as the successful realization of another theory of nature. In this way, the definition of what counted as a wellworking experimental trial was, in principle, open-ended. In the views of the relevant actors, nature might perhaps speak unexpected words, and the experimenter would be obliged to listen.

The notion of the experimental trial therefore carried with it a sense of indiscipline: the experimenter might not be fully in control of the scene. The thing might fail. It might fail for lack of technical competence on the part of the experimenter, or it might fail for want of theoretical resources required to display the phenomena as docile. ${ }^{80}$ Trials were undisciplined experiments, and these, like undisciplined animals, children, and strangers, might be deemed unfit to be displayed in public. This is why experimental trials were, in fact, almost invariably performed in relatively private spaces (such as Hooke's rooms and Boyle's laboratory) rather than in the public rooms of the Royal Society.

The weekly meetings of the Royal Society required not trials but shows and discourses. ${ }^{81}$ It was Hooke's job as curator of experiments to prepare these performances for the society's deliberation, instruction, and entertainment. His notes entitled "Dr. Hook's Method of Making Experiments" stipulate that the curator was to make the trial "with Care and Exactness," then to be "diligent, accurate, and curious" in "shewing to the Assembly of Spectators, such Circumstances and Effects . . . as are material." Even a visitor like Magalotti observed that he who was in charge of the society's experiments "does not come to make

\footnotetext{
79 Quotations are from Hooke's 1672-1680 Diary, pp. 27-29, 33. For Boyle's views on what counted as an experimental failure, see Shapin and Schaffer, Leviathan and the Air-Pump, pp. 185-201.

${ }^{80}$ For uses of Foucauldian notions of "discipline" and "docile bodies" in the sociology of scientific knowledge: Michael Lynch, "Discipline and the Material Form of Images: An Analysis of Scientific Visibility," Soc. Stud. Sci., 1985, 15:37-66; Bruno Latour, Science in Action: How to Follow Scientists and Engineers through Society (Milton Keynes: Open Univ. Press, 1987), Ch. 3.

${ }^{81}$ Historians concerned with other issues have known this for some time, e.g., Hunter, Science and Society in Restoration England (cit. n. 15), p. 46; Hunter and Wood, "Towards Solomon's House" (cit. n. 41), p. 76; and Penelope M. Gouk, "Acoustics in the Early Royal Society 1660-1680," Notes Rec. Roy. Soc., 1981-1982, 36:155-175, on p. 170.
} 
them in public before having made them at home." 82 Hooke had specific directions to this effect. For instance, in connection with a set of magnetic experiments, "It was ordered, that Mr. Hooke . . . try by himself a good number of experiments . . . and draw up an account of their success, and to communicate it to the Society, so that they might call for such of them as they should think good to be shewn before them." And in the case of a transfusion trial, Hooke and others were "appointed to be curators of this experiment, first in private by themselves, and then, in case of success, in public before the society." 83 Hooke did labor assiduously "at home," disciplining the trials and, when they had been made docile, bringing them to be shown.

He was a success at his job. His first biographer said that his experiments for the Royal Society were "performed with the least Embarrassment, clearly, and evidently." 84 There was always the risk of "embarrassment" precisely because these were to be not trials but shows, performed not in private but in public. "Embarrassment" was avoided, and the society had a successful meeting, when "the experiments succeeded," that is, when they met the shared expectations attending their outcome (and, presumably, when they offered a certain amount of amusement and entertainment).

But even Hooke did not always succeed. When an experimental show failed, the reasons were more circumscribed than in the case of a trial. With any event labeled as, and intended to be, a show, failure could mean only that the experimenter or the materials under his direction were in some way wanting. Accordingly, the Royal Society was not tolerant of failed shows. Hooke's wrist was smartly slapped when he produced in public the undisciplined phenomena that abounded in private settings: "The operator was ordered to make his compressing engine very staunch; and for that end to try it often by himself, that it might be in good order against the next meeting"; "Mr. Hooke was ordered to try this by himself at home"; "He made an experiment of the force of falling bodies to raise a weight; but was ordered to try it by himself, and then to shew it again in public."85

The relations between trials and shows, between activities proper to private and to public spaces, were, however, inherently problematic. The status of what had been produced or witnessed was a matter for judgment. A clear example of this is the case of the so-called anomalous suspension of water. In the early $1660 \mathrm{~s}$ there was serious dispute in the Royal Society over the factual existence and correct interpretation of this phenomenon. (Water that is well purged of air bubbles will not descend from its initial standing in the Torricellian apparatus when it is placed in an evacuated air pump. Boyle had pointed to descent as crucial

82 Philosophical Experiments of Hooke, ed. Derham (cit. n. 46), pp. 26-28; and Magalotti to Cardinal Leopold, 20 Feb. 1668, in Maddison, "Some Italian Visitors to the Royal Society" (cit. n. 32), p. 161.

${ }^{83}$ Birch, History of the Royal Society (cit. n. 23), Vol. III, p. 124 (entry for 12 Feb. 1674), and Vol. II, p. 115 (entry for 26 Sept. 1666).

${ }^{84}$ Richard Waller, "The Life of Dr. Robert Hooke," in The Posthumous Works of Robert Hooke ... , ed. Waller (London, 1705), pp. i-Xxviii, on p. iii (also quoted in Weld, History of the Royal Society [cit. n. 21], Vol. I, p. 438). Weld was one of the first historians to note this characteristic of Royal Society experiments: "These experiments were generally repetitions of experiments already made in private and exhibited afterwards for the satisfaction and information of the Society": p. 136n.

${ }^{85}$ Birch, History of the Royal Society (cit. n. 23), Vol. I, pp. 177, 194, 260 (entries for 14 Jan., 11 Feb., and 17 June 1663). 


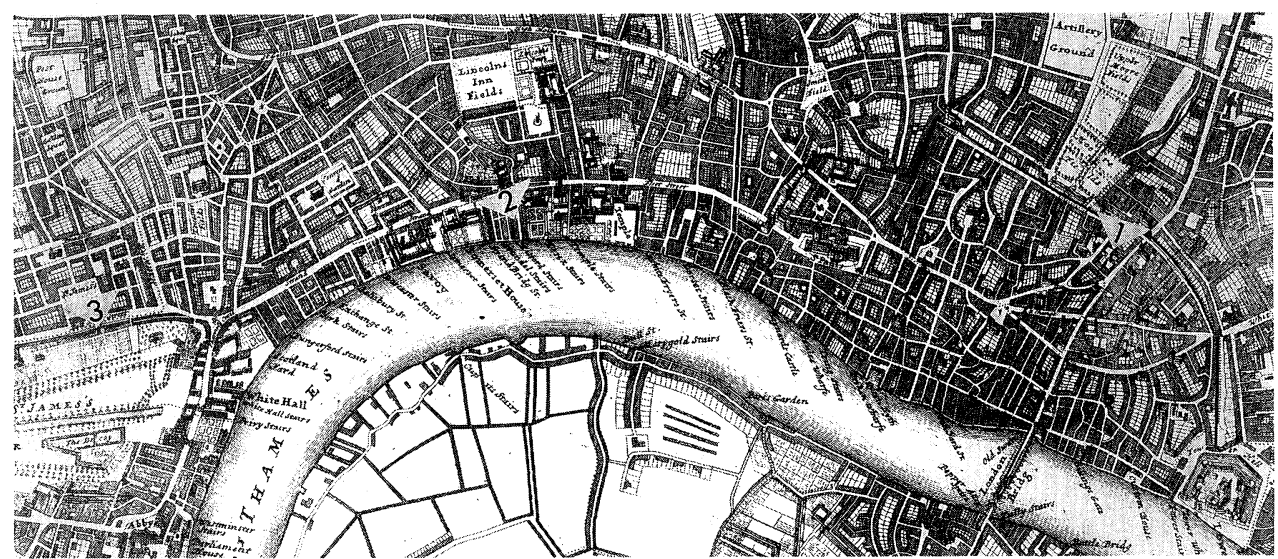

Figure 4. Detail from a map of London in the early eighteenth century, by John Strype, showing the relative locations of Gresham College (1), Arundel House (2), and Boyle's house and laboratory in Pall Mall (3). From John Stow, A Survey of the Cities of London and Westminster (London, 1720); courtesy of Special Collections, University of Edinburgh Library.

confirmation of his hypothesis of the air's spring.) Huygens had produced the alleged phenomenon in Holland, and Boyle disputed its status as an authentic fact of nature by suggesting that nondescent was due to the leakage of external air into Huygens's pump. Hooke was directed to prepare the experiment for the Royal Society. During the early phases of the career of anomalous suspension in England, the experimental leaders of the Royal Society were of the opinion that no such phenomenon legitimately existed. Any experiment that showed it was considered to have been incompetently performed-the apparatus leaked. Since members of the society had considerable experience of Hooke's bringing them experiments in pumps that were not "sufficiently tight," they readily concluded that Hooke's first productions of anomalous suspension were instances of experimental failure. ${ }^{86}$ The experimental phenomena had not been made sufficiently docile. Hooke had indeed tried the experiment at home and had deemed it ready to be shown. The leaders of the society concluded otherwise: Hooke had produced only a trial, a failed show. What Hooke claimed to be knowledge, the society rejected as artifact. They disputed his claim by stipulating that the thing was not proper to be shown in a public place. ${ }^{87}$

When the Royal Society was at Arundel House, its curator Robert Hooke was continually ordered to bring the air pump to their meetings from its permanent lodgings in Hooke's rooms a mile and a half away at Gresham (see Figure 4). In the course of being trundled back and forth, the brittle seals that ensured the machine against leakage were liable to crack, so that the curator's experimental 386.

${ }^{86}$ Ibid., pp. 139, 212, 218, 220, 238, 248, 254-255, 268, 274-275, 286-287, 295, 299-301, 305, 310,

${ }^{87}$ The story of anomalous suspension is told in Shapin and Schaffer, Leviathan and the Air-Pump (cit. n. 4), Ch. 6. The society ultimately came round to the view that anomalous suspension authentically existed, and, therefore, that experiments not revealing it were incompetent. This shift crucially involved Boyle's personal experience of the phenomenon and Huygens's visit to London to produce anomalous suspension before witnesses. For similar doubt of Hooke's experimental testimony, see "An Account of the Experiment made by Mr. Hook, of Preserving Animals Alive by Blowing through Their Lungs with Bellows," Phil. Trans., 21 Oct. 1667, No. 28, pp. 539-540. 
shows sometimes failed. Hooke made a modest proposal. He suggested that, in this one instance and for this circumscribed practical reason, the honorable fellows who wished to satisfy themselves how matters stood should come to him, instead of Hooke and the machine going to them. Hooke "moved that . . . a committee might be appointed to see some experiments made with [the air pump] at his lodgings." 88

An ad hoc committee was constituted and the visit to Hooke's rooms was made. In this instance, the normal pattern of movement in seventeenth-century experimental science was reversed: those who wanted to witness experimental knowledge in the making came to where the instruments permanently lived, rather than obliging the instruments to come to where witnesses lived. This inversion of the usual hierarchical ordering of public and private spaces was exceptional in seventeenth-century practice, and, in the event, it was rarely repeated. The showing of experimental phenomena in public spaces to a relevant public of gentlemen witnesses was an obligatory move in that setting for the construction of reliable knowledge. What underwrote assent to knowledge claims was the word of a gentleman, the conventions regulating access to a gentleman's house, and the social relations within it.

The contrast with more modern patterns is evident. The disjunction between places of residence and places where scientific knowledge is made is now almost absolute. The separation between the laboratory and the house means that a new privacy surrounds the making of knowledge whose status as open and public is often insisted upon. The implications of this disjunction are both obvious and enormously consequential. Public assent to scientific claims is no longer based upon public familiarity with the phenomena or upon public acquaintance with those who make the claims. We now believe scientists not because we know them, and not because of our direct experience of their work. Instead, we believe them because of their visible display of the emblems of recognized expertise and because their claims are vouched for by other experts we do not know. Practices used in the wider society to assess the creditworthiness of individuals are no longer adequate to assess the credibility of scientific claims. We can, it is true, make the occasional trip to places where scientific knowledge is made. However, when we do so, we come as visitors, as guests in a house where nobody lives.

88 Birch, History of the Royal Society, Vol. II, p. 189 (entry for 25 July 1667). 